2019-06

\title{
Methods of Usability Testing in the Development of eHealth Applications: A Scoping Review
}

\section{Maramba, Inocencio Daniel}

http://hdl.handle.net/10026.1/13696

\begin{abstract}
10.1016/j.jimedinf.2019.03.018
International Journal of Medical Informatics

Elsevier
\end{abstract}

All content in PEARL is protected by copyright law. Author manuscripts are made available in accordance with publisher policies. Please cite only the published version using the details provided on the item record or document. In the absence of an open licence (e.g. Creative Commons), permissions for further reuse of content should be sought from the publisher or author. 


\title{
Methods of Usability Testing in the Development of eHealth Applications: A Scoping Review
}

\author{
Inocencio Maramba, Arunangsu Chatterjee, Craig Newman \\ Peninsula Medical School, Faculty of Medicine and Dentistry. University of Plymouth, Drake Circus, Plymouth, \\ PL4 8AA. United Kingdom
}

Corresponding Author: Inocencio Maramba

\begin{abstract}
Background: The number of eHealth applications has exponentially increased in recent years, with over 325,000 health apps now available on all major app stores. This is in addition to other eHealth applications available on other platforms such as PC software, web sites and even gaming consoles. As with other digital applications, usability is one of the key factors in the successful implementation of eHealth apps. Reviews of the literature on empirical methods of usability testing in eHealth were last published in 2015. In the context of an exponentially increasing rate of App development year on year, an updated review is warranted.
\end{abstract}

Objective: To identify, explore, and summarize the current methods used in the usability testing of eHealth applications.

Methods: A scoping review was conducted on literature available from April 2014 up to October 2017. Four databases were searched. Literature was considered for inclusion if it was (1) focused on an eHealth application (which includes websites, PC software, smartphone and tablet applications), (2) provided information about usability of the application, (3) provided empirical results of the usability testing, (4) a full or short paper (not an abstract) published in English after March 2014. We then extracted data pertaining to the usability evaluation processes described in the selected studies.

Results: 133 articles met the inclusion criteria. The methods used for usability testing, in decreasing order of frequency were: questionnaires $(n=105)$, task completion $(n=57)$, 'Think-Aloud' $(n=45)$, interviews $(n=37)$, heuristic testing $(n=18)$ and focus groups $(n=13)$. Majority of the studies used one $(n=45)$ or two $(n=46)$ methods of testing. The rest used a combination of three $(n=30)$ or four $(n=12)$ methods of testing usability. None of the studies used automated mechanisms to test usability. The System Usability Scale (SUS) was the most frequently used questionnaire $(n=44)$. The ten most frequent health conditions or diseases where eHealth apps were being evaluated for usability were the following: mental health $(n=12)$, cancer $(n=10)$, nutrition $(n=10)$, child health $(n=9)$, diabetes $(n=9)$, telemedicine $(n=8)$, cardiovascular disease $(n=6)$, HIV $(n=4)$, health information systems $(n=4)$ and smoking $(n=4)$. Further iterations of the app were reported in a minority of the studies $(\mathrm{n}=41)$. The use of the 'Think-Aloud' (Pearson Chi-squared test: $\chi 2=11.15, \mathrm{p}<0.05$ ) and heuristic walkthrough (Pearson Chi-squared test: $\chi 2=4.48, \mathrm{p}<0.05$ ) were significantly associated with at least one further iteration of the app being developed.

Conclusion: Although there has been an exponential increase in the number of eHealth apps, the number of studies that have been published that report the results of usability testing on these apps has not increased at an equivalent rate. The number of digital health applications that publish their usability evaluation results remains only a small fraction. Questionnaires are the most prevalent method of evaluating usability in eHealth applications, which provide an overall measure of usability but do not pinpoint the problems that need to be addressed. Qualitative methods may be more useful in this regard. The use of multiple evaluation methods has increased. Automated methods such as eye tracking have not gained traction in evaluating health apps. Further research is needed into which methods are best suited for the different types of eHealth applications, according to their target users and the health conditions being addressed.

Keywords: eHealth, mHealth, Mobile, Usability, Applications, Health informatics. 


\section{Introduction}

eHealth is emerging as a key sector for delivering health in UK. There are government calls to enable this, and funding is being made available for national and regional programmes to expand the use of eHealth. This is outlined in the National Health Service (NHS) Five Year Forward View, which aims to put together "An expanding set of NHS accredited health apps that patients will be able to use to organise and manage their own health and care"[1]. In the recently released NHS Long Term Plan, one of the stated aims is for digitally enabled care to go mainstream across the NHS. This includes working with the wider NHS, the voluntary sector, developers, and individuals in creating a range of apps to support particular conditions [2]. There has also been simultaneous phenomenal growth in the eHealth application market. A recent report stated that there were over 3.7 billion downloads of mobile health applications in 2017, an increase of $16 \%$ from the year before. There were 325,000 health apps (health \& fitness and medical apps) available on all major app stores, with, 78,000 new health apps have been added to major app stores in 2017 alone [3]. However, fitting digital solutions onto health problems is not an easy task. Attempts to scale up digital health implementations from pilots and demonstrators have proven to be difficult or in some cases, unsuccessful [4-6].

According to a report published by the Institute of Medicine, "usability and health literacy strategies should guide the development of mHealth apps"[7]. Usability has been identified as a key component of good practice in the development of digital applications [8], and a number of published standards have identified usability as an essential criteria for the assessment of digital applications in health, such as the NHS Digital Assessment Questionnaire [9], the guidance from the Medicines and Healthcare products Regulatory Agency [10], the Organisation for the Review of Care and Health Applications [11], and Our Mobile Health [12]. The International Organization for Standardization has defined usability as, "the extent to which a product can be used by specified users to achieve specified goals with effectiveness, efficiency and satisfaction in a specified context of use" [13]. Usability becomes a vital factor in the adoption of digital health applications, as the people who need to use them may have problems when using mobile devices due to their health conditions [8]. There is a need to ensure that health technologies are appropriately designed and targeted to the end-users' needs before they are used as health interventions [14]. This can be achieved by applying robust methods of evaluation to ensure good usability. Conducting usability evaluation on eHealth applications will have enormous value for patient benefit, as better usability can lead to a number of benefits, including improved productivity, enhanced user well-being, avoidance of stress, increased accessibility and reduced risk of harm, which is stated in the International Standards Organization standard for Ergonomics of Human Computer Interaction (ISO 9241-210) [15]. Another benefit would be greater acceptance, as clinicians' acceptance of and attitudes towards EHR systems have been shown to relate closely to system usability [16-18].

In 2014, Zapata et al reviewed empirical usability methods for mobile applications, in health, analysing 22 studies [8]. They identified several areas for further research including; (a) a combination of two or more different types of usability methods, (b) automation of usability evaluation methods, (c) adoption of iterative usability evaluation processes and (d) validation of the reliability of the evaluation methods employed. At the time of that review, the number of medical applications in app stores was estimated at 28,000 (20,000 iOS and 8,000 Android). Since then, the number of available health apps has increased more than tenfold. It is very likely that the health conditions they address, the publication channels for usability studies, and perhaps the types of usability evaluation methods employed have changed or broadened. Thus, it is time to re-investigate how usability testing methods for eHealth applications are described in the literature published since April 2014.

The aim of this study was to identify, explore, and summarise the current state of the literature on usability testing of eHealth applications since 2014 through a scoping review. We chose to do a scoping review as our aim is to map the literature or evidence rather than seek to answer a specific question by only looking for the best available information, as defined in the Joanna Briggs Institute reviewers' manual 2015: Methodology for JBI scoping reviews [19]. This is similar to the mapping studies in software engineering described by Kitchenham [20].

We used the following research questions to guide our review: (1) What is the current state of the literature that addresses usability testing for developing eHealth applications? (2) What are the usability testing methods that are being used in the development of eHealth applications? (3) What health conditions / diseases are being addressed by the apps that employ usability testing? (4) What types of people are being recruited to be the participants in the usability tests? (4) How has the number of published studies regarding usability testing of eHealth applications changed over time? (5) What are the types of journals where usability evaluations of 
eHealth applications are reported? And (6) How many of the published studies employed an iterative development method?

The inclusion of a usability section in the NHS Digital Assessment Questionnaire for apps seeking to be included in the NHS apps library is proof that usability evaluation is a crucial part for acceptance of eHealth apps into the healthcare system. Thus, knowledge about the proper use of the methods of usability testing will be useful for developers, commissioners, healthcare professionals, patient participation groups and other researchers. It will provide an overview of the state of usability evaluation in eHealth as reported in the literature. This can then provide a guide for developers, as well as inform the other eHealth stakeholders about the methods used for usability evaluation.

Our main aim is to investigate what academia has contributed to the employment of usability evaluation methods in the development of eHealth. We are conscious that a lot of eHealth app development is done outside of academia - but in the context of increasing policy standards, governance bodies are looking for evidencebased standards, with peer-reviewed evidence, being the gold standard[21]. This review of the peer-reviewed literature will provide a baseline for that process.

Materials and methods

We selected a systematic scoping review as the method, keeping in mind that our aim was to map the literature on usability testing in eHealth since 2014.

Information sources

We examined a variety of information sources, searching four electronic databases from medicine, nursing, allied health, computer and engineering sciences: The Association for Computing Machinery Digital Library (ACM DL), the Cumulative Index to Nursing and Allied Health Literature (CINAHL), the Institute of Electrical and Electronics Engineers (IEEE) Xplore Digital Library, and Medline / PubMed.

Search strategy

The search strategy was developed by one of the authors (IM). The general search terms were eHealth, mHealth and usability. Searches were conducted between the months of June 2017 and November 2017 for articles up to 31 October 2017.

For Medline / PubMed, the following search string was used:

(("telemedicine"[MeSH Terms] OR "telemedicine"[All Fields] OR "ehealth"[All Fields]) AND usability[All Fields]) OR (("telemedicine"[MeSH Terms] OR "telemedicine"[All Fields] OR "mhealth"[All Fields]) AND usability[All Fields])

For all other databases, this search string was employed:

(ehealth OR mhealth or telemedicine) AND (usability)

Inclusion and exclusion criteria

Any literature about eHealth applications using empirical methods of usability testing published between April 2014 and October 2017 was considered. Literature was considered for inclusion if it met the following criteria:

IC1. The paper is focused on an eHealth application, which includes websites, PC software, smartphone and tablet applications.

IC2. The paper provides information about usability of the application.

IC3. The paper provides empirical results.

IC4. The paper evaluates an application for final users, not just a wireframe or low fidelity prototype.

IC5. The paper must be a full or short paper (not an abstract).

Studies were excluded if:

EC1. The paper is not written in English.

EC2. The paper was published after October 2017 or before April 2014

EC3. The paper evaluates a medical device, or smart device, a service, a smartphone or tablet feature (not an app), or software that is not an eHealth application. 
EC4. The paper is not a primary empirical study of an eHealth application (e.g. a review or theory paper).

EC5. The paper does not adequately describe the methods used for usability evaluation or does not report the results of the usability evaluation or is an evaluation of a low fidelity prototype or wireframe, or is only the research protocol of a usability evaluation, or is not a full paper (e.g. poster or abstract).

Search results and selection of literature

One author (IM) searched the four selected databases which yielded 1420 individual articles for possible inclusion in this scoping review. After removing the duplicate citations $(n=140)$, the same author reviewed the titles and abstracts of 1280 citations for inclusion, which resulted in the removal of another 1104 papers. The full text of each of the remaining 176 articles was then screened by IM using the inclusion/exclusion criteria, yielding a final sample of 133 papers, all of which were from published, peer-reviewed literature. Fig. 1 shows the systematic process followed for identifying and selecting literature.

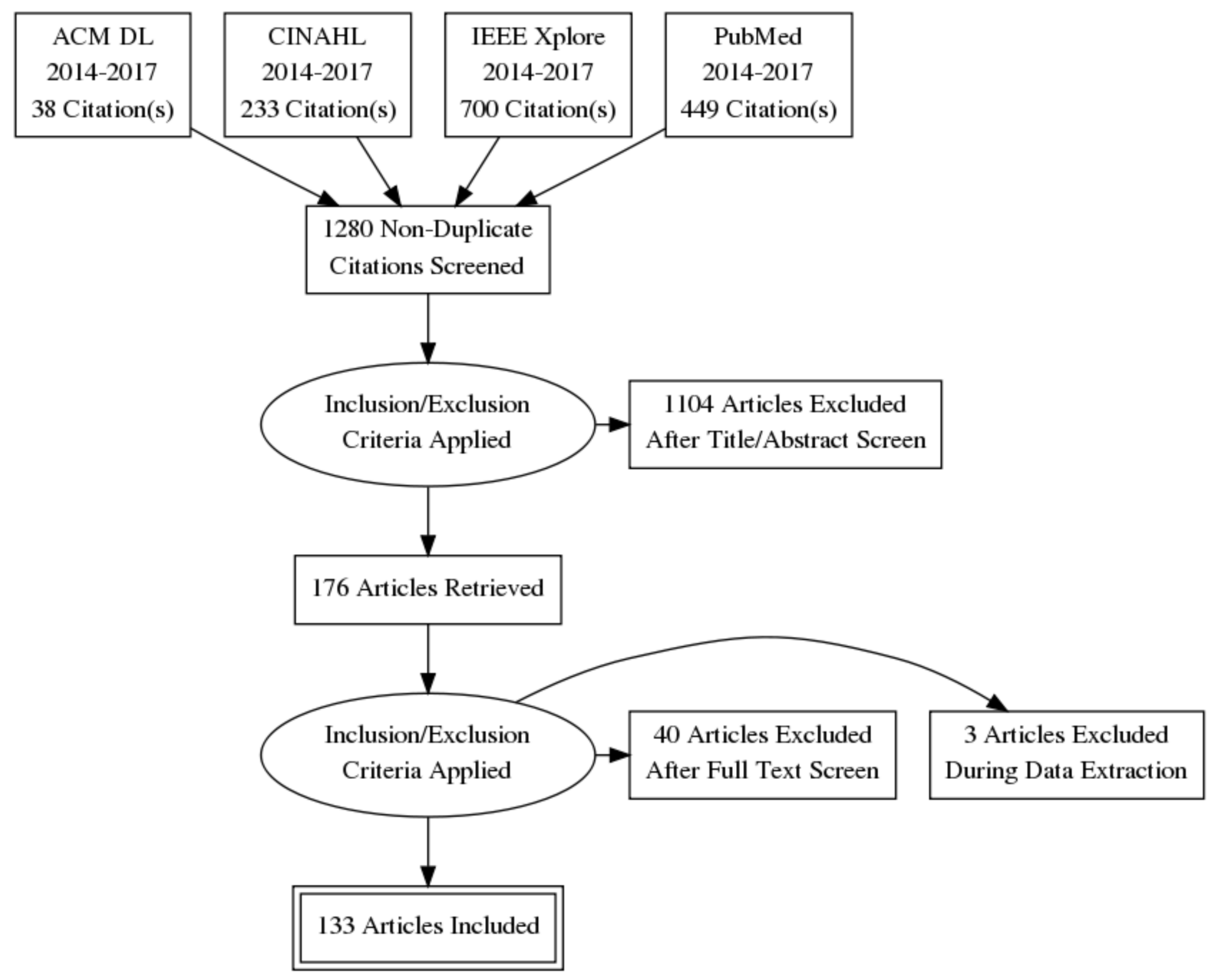

Figure 1. Flowchart of article selection.

Data extraction and categorisation

General and specific information about the 131 articles was extracted including: title of the article; author's name; source of publication; publication year; country of origin; health condition / disease addressed by the app ; whether the app was for patient self-management, behavioural change, patient education, or stored / transferred clinical data ; if the app was used in primary, secondary or home care ; the type of usability testing method used ; the type of questionnaire used and if a reference to published literature about the questionnaire was included; the nature of the participants in the usability testing; whether a citation for the chosen sample size was included; whether qualitative methods were employed and if so, what type; the device platform of the eHealth application under study; and whether iterative methods were used for the app after usability testing.

Data extracted from each article were recorded on a computer worksheet (Excel and Libreoffice) in order to categorise and compare characteristics, as well as to prepare the data for export to .CSV format for analysis with 
statistical software. As this was a scoping review and the focus was on mapping the methods used and not the best available evidence, critical appraisal of the selected articles was not performed.

Analysis

We cleaned the dataset using GNU PSPP and performed quantitative analysis using the R statistical programming software. We calculated descriptive statistics, consisting mostly of frequency tables for the categorical variables. We summarised the findings from the selected articles to answer the research questions that guided this study.

\section{Results}

Summary of the selected literature

We identified 133 articles for this scoping review after applying the inclusion and exclusion criteria. Research based articles comprised $93.9 \%(n=125)$ of the selected literature. The dates of publication ranged from 2014 to 2017 , with the majority $(88.72 \%, \mathrm{n}=118)$ published in $2016-2017$. The most commonly used methods for usability testing were questionnaires, task completion, "Think-Aloud" protocol, interviews, heuristic testing and focus groups. A majority (67.17\%) of studies used at least two methods of usability testing. The five most frequent diseases or health conditions where usability evaluations are being applied were mental health, cancer, nutrition, child health and diabetes. A majority of the applications $(75.9 \%, n=101)$ were evaluated by real users: patients, health care professionals (doctors, nurses, etc), or caregivers. Only a small number $(6 \%, n=8)$ of applications were evaluated by heuristics experts alone. Most of the studies $(64.66 \%, \mathrm{n}=86)$ were published in health informatics journals, with the remaining studies published in medical, allied health, computing and engineering journals. A little less than a third $(30.08 \%, \mathrm{n}=41)$ of the studies reported at least one more iteration of the application being developed after the usability testing. We also identified the intended user of the applications under evaluation and found that 85 of the applications had patients as their intended primary user, 28 had clinicians as the primary user, and 20 applications were intended to be used by both patients and clinicians. Table A1 in Appendix A provides an overview of the articles included in the scoping review. The following sections discuss these findings in greater detail.

Usability testing methods employed

Six different usability testing methods were utilized in the selected papers: Two quantitative methods $(\mathrm{n}=115)$ such as (1) Questionnaires, and (2) task completion; three qualitative methods (n=70) (3) "Think-Aloud" protocol, (4) interviews, and (5) Focus groups; and (6) Heuristic testing $(n=18)$. The frequency of these methods as well as their intersection is illustrated by the Venn diagram in Figure 2.

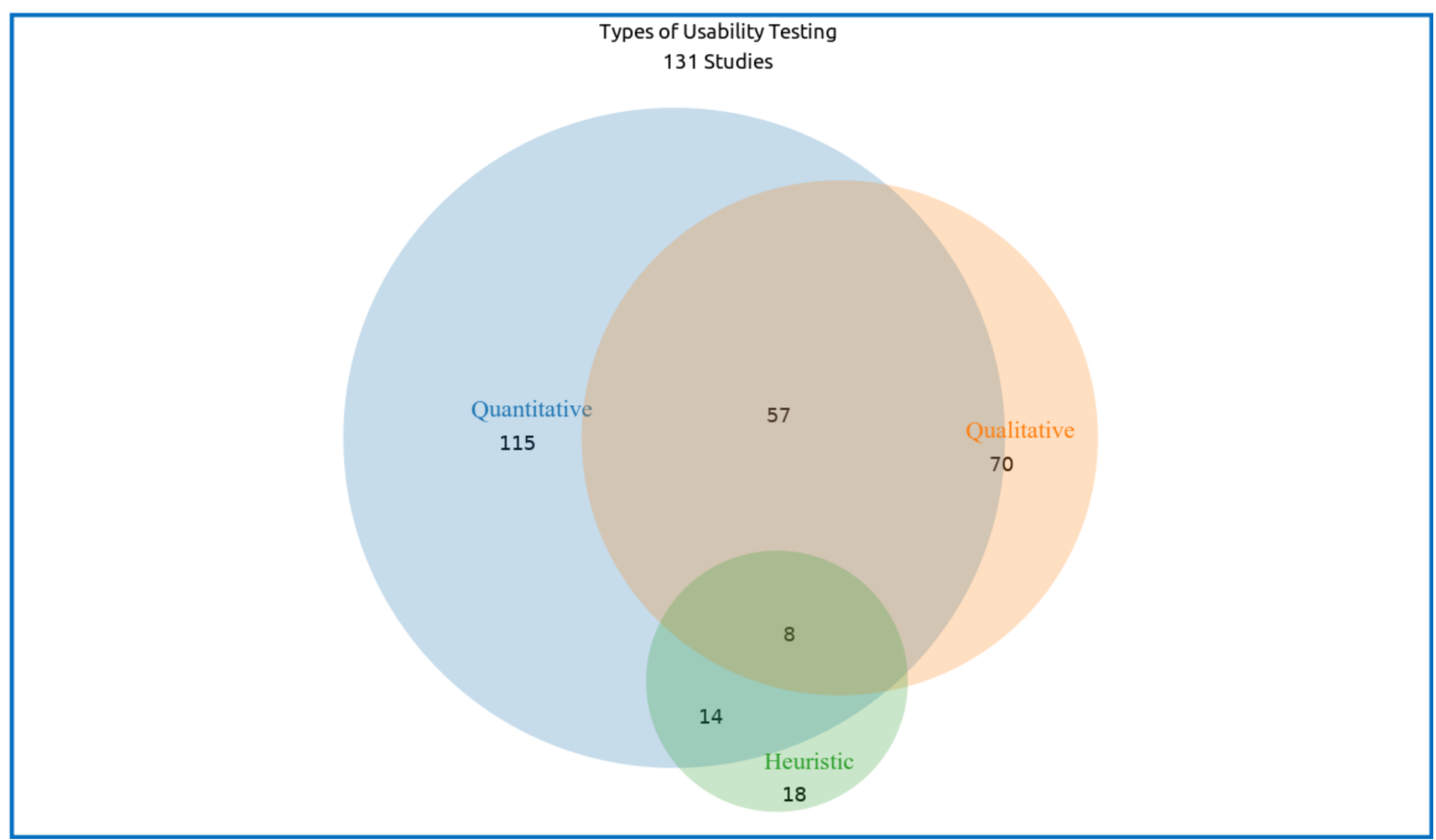

Figure 2: Usability Evaluation methods employed. 
There were eight studies that used all three types of usability evaluation methods. Of the eight studies, two were on an app for fall prediction detection[22,23], and one each for apps dealing with breast cancer[24], exercise coaching + diabetes + depression[25], Health Data Visualisation[26], Telemedicine[27], HIV[28], and Dental health[29].

Figure 3 shows the which quantitative methods were employed, their frequency, and how many were combined with qualitative methods:

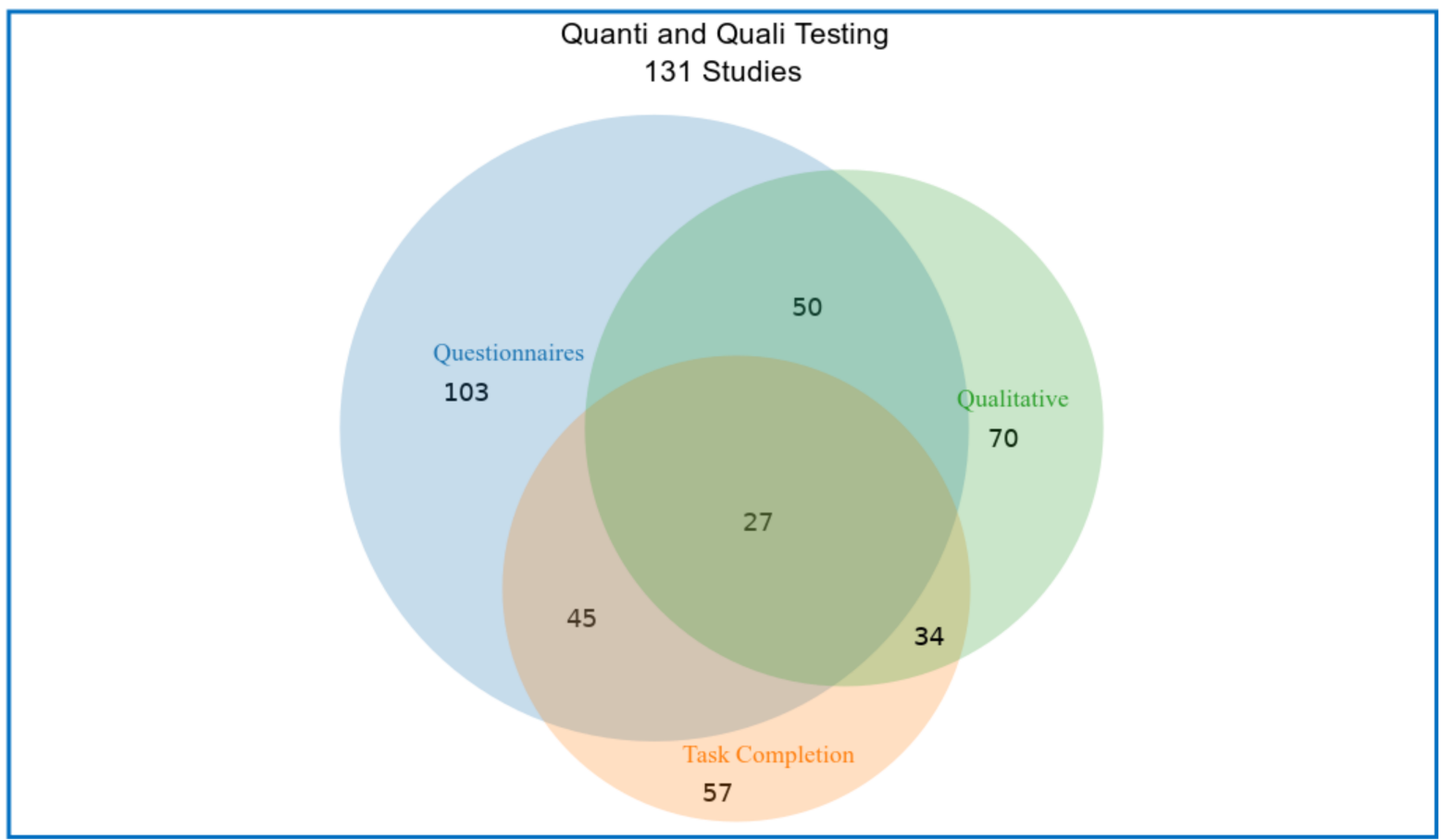

Figure 3: Quantitative and qualitative testing methods.

The quantitative method most frequent used to evaluate the usability of an application was questionnaires $(\mathrm{n}=105)$. Task completion was employed in 57 of the studies. 45 studies used questionnaires in conjunction with task completion, while 50 studies combined questionnaires with a qualitative method. Task completion was used with qualitative methods in 34 studies, and 27 studies used questionnaires together with task completion as well as a qualitative method.

Figure 4 shows which qualitative methods were employed to evaluate usability:

The most frequently used qualitative method was 'Think-Aloud' ( $\mathrm{n}=45)$, followed by interviews ( $\mathrm{n}=37$ ), and focus groups $(\mathrm{n}=13) .18$ studies used a combination of "Think-Aloud" and interviews, while 5 studies used Interviews and focus groups. The combination of Think aloud and focus groups was employed in 3 studies and one study used all three qualitative methods.

The most frequently used validated questionnaire was the System Usability Scale task completion (33.59\%, $\mathrm{n}=44)$. Other validated questionnaires used were the Post-Study System Usability Questionnaire $(9.16 \%, \mathrm{n}=12)$, Technology Acceptance Model Questionnaire $(3.82 \%, \mathrm{n}=5)$ and the Task Index $(1.52 \%, \mathrm{n}=2)$. These questionnaires were non-specific for the health IT domain. Three studies used a questionnaire designed specifically for eHealth: the AdEQUATE (questionnAire for Evaluation of QUAlity in TElemedicine systems) [30-32]. 


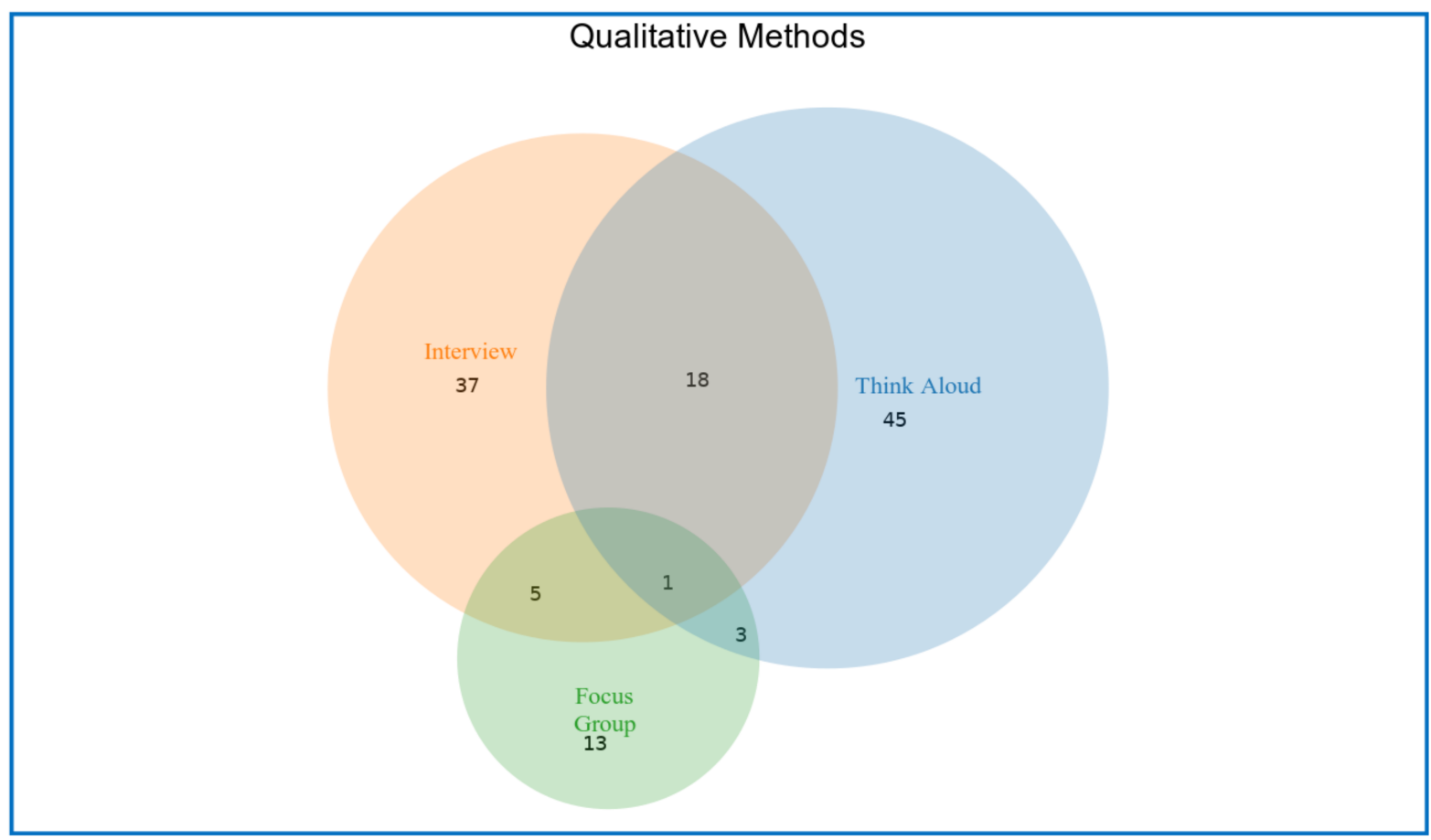

Figure 4: Qualitative methods of usability testing.

We then looked at whether the use of single or multiple usability evaluation methods differed according to the intended user of the application. The results are shown in the following table

\begin{tabular}{|l|r|r|r|}
\hline & Clinician & Dual & Patient \\
\hline Single & 11 & 8 & 24 \\
\hline Multi & $42.31 \%$ & $40.00 \%$ & $28.24 \%$ \\
\hline & 15 & 12 & 61 \\
\hline Total & $57.69 \%$ & $60.00 \%$ & $71.76 \%$ \\
\hline
\end{tabular}

Table 1: Single or multiple usability evaluation methods and intended users.

For all intended users, the use of a multimodal usability evaluation was more prevalent, being used in 88 (67.17\%) studies. Applications where the intended users were patients / caregivers had a higher proportion of use of multimodal methods ( $71.76 \%$ for patients compared with $57.69 \%$ for clinicians). There was no significant difference in the types of usability evaluation methods used for each type of intended user, for example, the proportion of studies using questionnaires did not vary according to the intended user, as seen in the table below: 


\begin{tabular}{|l|l|}
\hline $\begin{array}{l}\text { Primary } \\
\text { User }\end{array}$ & $\begin{array}{l}\text { Questionnaires } \\
(\%)\end{array}$ \\
\hline Clinician & $19(14.50)$ \\
\hline Dual & $15(11.45)$ \\
\hline Patient & $69(52.67)$ \\
\hline
\end{tabular}

Table 2: Number of studies using questionnaire according to intended users.

Health conditions / diseases addressed by the eHealth application

The ten most frequent health conditions or diseases where eHealth apps were being evaluated for usability are shown in Table 2. All in all, we identified 48 health conditions / diseases that were addressed by the apps in the selected literature. The complete range of health conditions can be found in the appendix.

\begin{tabular}{|l|l|l|}
\hline Health Condition/ Disease & Frequency & Percent (n=131) \\
\hline Mental Health & 12 & 9.16 \\
\hline Cancer & 10 & 7.63 \\
\hline Nutrition & 10 & 7.63 \\
\hline Child Health & 9 & 6.87 \\
\hline Diabetes & 9 & 6.87 \\
\hline Telemedicine & 8 & 6.11 \\
\hline CVD & 6 & 4.58 \\
\hline HIV & 4 & 3.05 \\
\hline Health Info System & 4 & 3.05 \\
\hline Smoking & 4 & 3.05 \\
\hline
\end{tabular}

Table 3: Ten most frequent health conditions in selected studies.

Participants in the usability testing

Most of the studies $(78.62 \%, \mathrm{n}=103)$ had only one type of user as a participant in usability evaluations, e.g., Patients only or Health Care Professionals only. When we categorise the studies according to the types of participants, we get the following Venn Diagram:

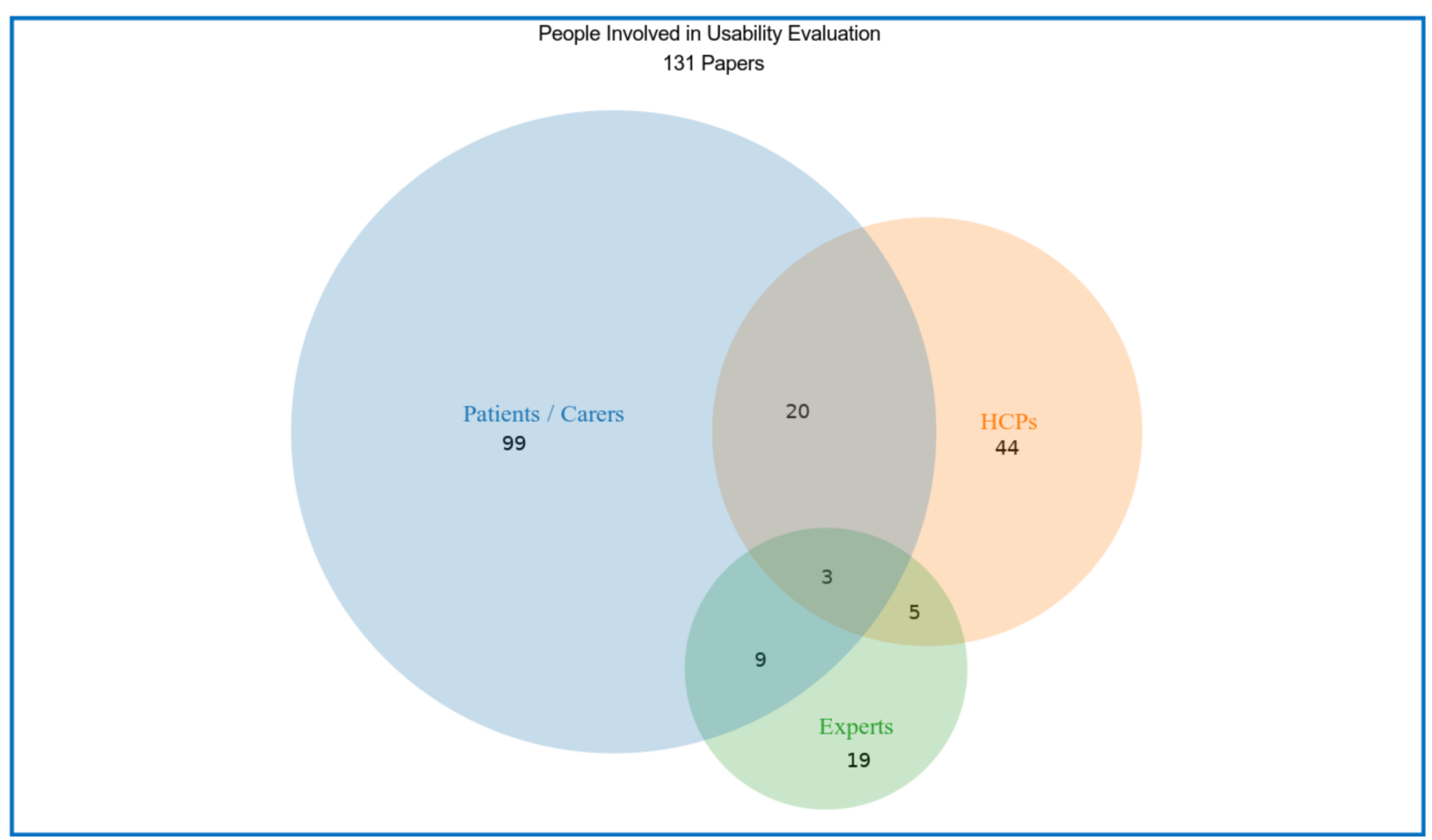

Figure 5: Participants in usability testing. 
Patients / Carers were participants in the usability testing of 99 of the studies. HCP's were involved as participants in 44 of the studies and heuristic experts in 19. Twenty studies had both Patients / Carers and HCP's as participants, while the combination of Patients / Carers and heuristic experts were involved in 9 studies. Five studies utilised both HCPs and heuristic experts, and three of the studies involved Patients / Carers, HCPs and heuristic experts in usability testing. In studies that used only one class of tester, 73 were Patients / Carers only, 22 were tested only by HCPs, and eight had only heuristic experts as participants.

Only $25.95 \%(n=34)$ of the studies cited a reference as their justification for the number of participants.

The number of participants varied according to the type of testing used, whether heuristic evaluation, qualitative, quantitative or multi-modal. The number of participants according to the type of testing is shown in the following table:

\begin{tabular}{|l|l|l|l|}
\hline Type of test & Mean & Minimum & Maximum \\
\hline All types & 40 & 1 & 450 \\
\hline Heuristic only & 3.67 & 1 & 5 \\
\hline Qualitative only & 13.69 & 4 & 32 \\
\hline Quantitative only & 52.70 & 2 & 373 \\
\hline Multi-method & 35.21 & 4 & 450 \\
\hline
\end{tabular}

Table 4: Number of participants according to type of usability evaluation method.

Studies which only used heuristic methods had the least number of participants, and studies which only used quantitative methods had the greatest number of participants.

Timeline and publication channels for reports of usability testing of eHealth applications

Figure 6 shows the number of articles published for each of the years included in the search,

\section{Number of Papers per year}

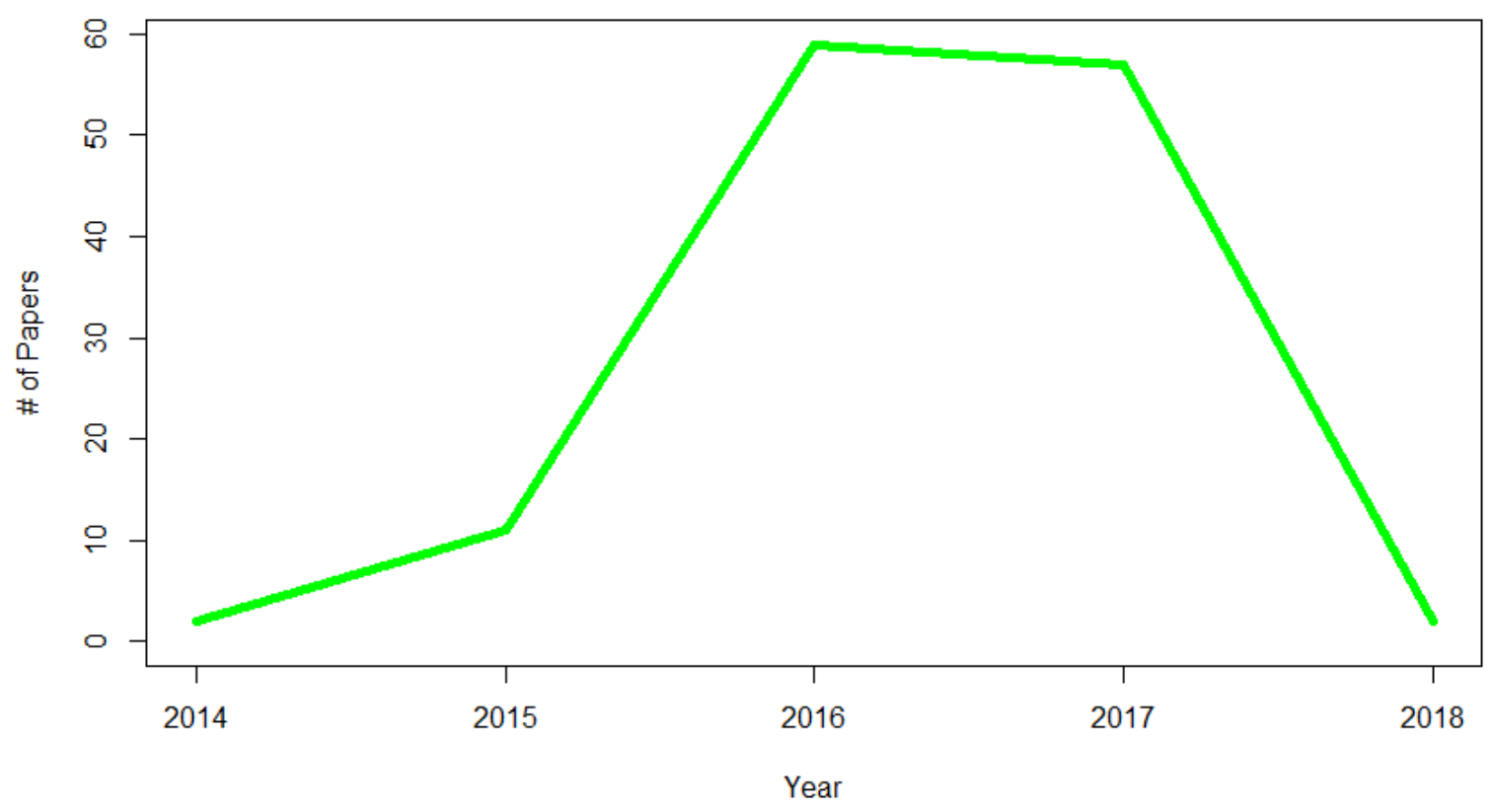

Figure 6: Timeline of publication of usability studies.

NB. 2018 was cited in the database as the publication year for 2 of the articles, although they were available online in 2017. Figure 7 shows the types of journals that the articles were published in according to the year of publication: 


\section{Number of Articles Published by Year and type of Journal}

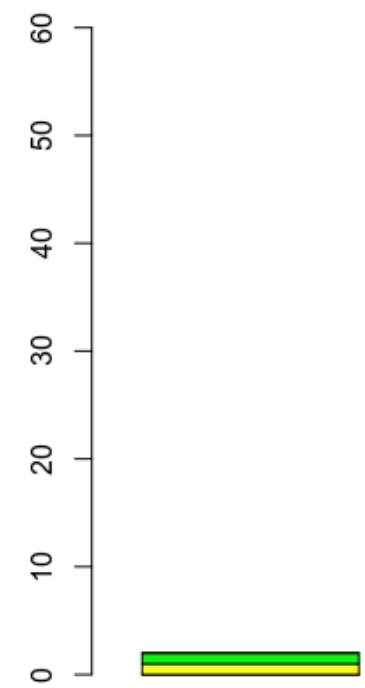

2014

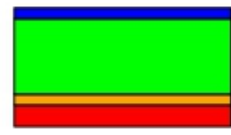

2015

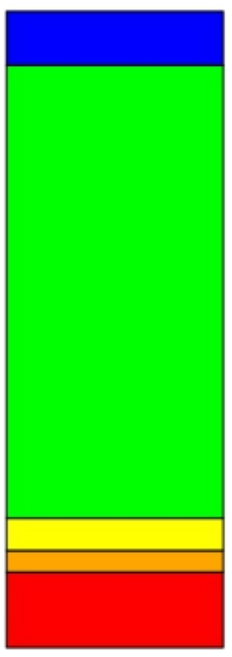

2016
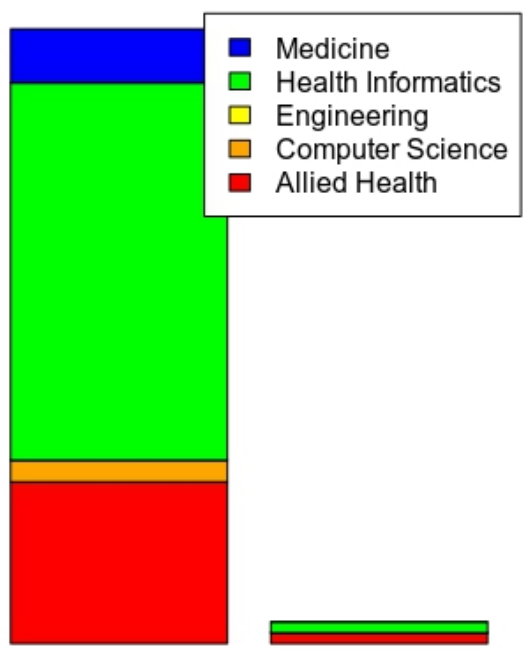

2017

2018

Year

Figure 7: Types of journals that usability studies were published.

As can be seen in the graphs, most of the selected papers were published in $2016(n=59)$ and $2017(n=57)$.

Health Informatics journals were the main publication channel in the selected literature, accounting for $65 \%$ $(n=86)$ of the selected articles. Other publication channels were medical journals, allied health, computer science, and engineering journals. The table showing all the publication types is shown here:

\begin{tabular}{|l|l|l|}
\hline Publication type & Frequency & Percent \\
\hline Health Informatics & 88 & 67.17 \\
\hline Allied Health & 25 & 18.79 \\
\hline Medicine & 11 & 8.27 \\
\hline Computer Science & 5 & 3.76 \\
\hline Engineering & 4 & 3.01 \\
\hline Total & $\mathbf{1 3 3}$ & $\mathbf{1 0 0 . 0}$ \\
\hline
\end{tabular}

Table 5: Types of publications where usability evaluations were published.

Iterative model of development

We wanted to see if any of the articles mentioned the development of further iterations of the app as a result of the usability testing, as the iterative approach is cited as an important component of health intervention development $[15,16]$. We found that 41 out $131(31.3 \%)$ of the studies reported that at least one further iteration of the app was developed following the results of the usability testing.

We performed a Chi-squared test of association using $2 \times 2$ tables to see if iterative development was associated with the type of usability testing done. The use of the Think Aloud protocol and Heuristic testing were significantly associated with a report of further iterative development, whereas questionnaires, task completion, interviews and focus groups were not associated with a report of another iteration of the app. The table is shown here:

\begin{tabular}{|l|r|r|r|}
\hline & Non-Iterative & Iterative & \multicolumn{2}{l|}{} \\
\hline Think Aloud & $16.79 \%$ & $17.56 \%$ & $11.15^{*}$ \\
\hline Questionnaires & $52.67 \%$ & $25.95 \%$ & 0.34 \\
\hline Task Completion & $29.77 \%$ & $13.74 \%$ & 0.00 \\
\hline Heuristic & $6.11 \%$ & $7.63 \%$ & $4.48 *$ \\
\hline
\end{tabular}




\begin{tabular}{|l|r|r|r|}
\hline Interview & $17.56 \%$ & $10.69 \%$ & 0.65 \\
\hline Focus Group & $6.87 \%$ & $3.05 \%$ & 0.00 \\
\hline & & & $* \mathrm{p}<0.05$ \\
\hline
\end{tabular}

Table 6: Usability method and iterative development.

Discussion

Key findings

Findings in this scoping review suggest that together with the rapid growth of the number of eHealth applications, the number of studies that report the usability testing findings in eHealth app development is likewise increasing. Twenty-two studies were included in the review for the period of 2010-2014 when there were 28,000 health apps on the app stores [8]. For the years 2014-2017, the number of studies that reported the results of usability testing has increased to 131, a six-fold increase, while the number of apps has grown more than 10 times, with 325,000 reported in 2017 [3]. The increase in the number of published usability studies has grown at a slower rate than the number of digital health applications available. It should be noted that most digital health applications are found in commercial "app stores" such as those of Apple and Google, and are developed by commercial developers, rather than the academe. This sector does not normally publish results of their usability studies, which they may view as giving away a competitive advantage. It also illustrates an apparent non-involvement of academia in this rapidly growing area.

The health conditions / clinical areas being targeted by the apps have also expanded, with 13 being reported in 2014, whereas we found 48 distinct clinical areas being addressed by the apps in the selected literature. The clinical areas being addressed by digital health applications has clearly expanded.

However, the methods being used to test usability have remained unchanged since 2014. Despite the recommendation of a previous review [8] to utilise more objective and automated methods of usability testing, none of the selected studies used these methods, for example eye tracking and remote monitoring. A few of the studies used transmitted logs to record simple things like number of times the app was used and task completion. While these automated methods are well reported and utilised in other domains [33], there may be factors such as cost of equipment (e.g. eye trackers) that make the adoption of these methods prohibitive to developers, especially small to medium enterprises (SMEs). There may also be factors unique to the healthcare domain that inhibit the adoption of these methods.

Patients and caregivers are very much involved in usability testing, accounting for the largest proportion of participants. Health care professionals are also involved in the testing, mostly when the app is made for use by the health care professional, but also in cases where patient entered data is meant to be reviewed by the health care professional. The need to test both users is being recognised in these cases. However, the sample size is not being given much attention in these studies, as only a quarter of them reported a reference to validate the choice of a sample size. Studies where heuristic experts were the participant constituted only a small proportion of the selected literature, indicating a shift towards a more patient-centred approach to eHealth app development. This reflects recent calls for a more participatory design approach to eHealth application development, as well as the adoption of iterative methods [34].

Most of the selected literature were published in 2016 and 2017, coinciding with the growth in the eHealth App market as well as in the increase in the number of channels for publication of these type of studies. Health Informatics journals, which have increased in number in past few years, were the publication channel for most of the selected articles. In addition to the health informatics journals, allied health and medical journals were the second most employed publication channel. In contrast to the review 2014, computer science and engineering journals were in the minority with respect to publication channels, although this may have been affected by the choice of the databases searched in 2014 (i.e., the non-inclusion of Medline / PubMed and CINAHL). It may be useful for future usability studies of eHealth applications to be submitted to Human Computer Interaction and User Experience journals to improve awareness an increase uptake of more robust and object methods of usability testing.

Iterative design has been recognised as the key to enabling rapid development of successful products, using usability data to remove human factors as a barrier to success. Iterative development is the means of accommodating the life cycle of a product in an ever changing market[35,36]. Yet, the number of studies where the usability testing results were used to create another iteration of the app were in the minority accounting for less than a third of the included studies. The use of an iterative development strategy was seen in 41 out of the 
131 papers reviewed (31.3\%). This is very similar to the proportion of papers found in a previous review [8], where 7 out of $22(31.8 \%)$ studies used an iterative development strategy. It may be that the majority of the apps were in the final stages of development and some iteration had already taken place prior to the study being reported, or the initial iteration of the application already had good usability. We noted that the Think Aloud protocol and the heuristic walkthrough were significantly associated with iterative development, however various factors including study aims, previous work and other factors taken in context would have influenced the choice of the evaluation method.

Gaps and potential for future research

We see several areas that have a potential for opportunities and the need for future research. The use of objective automated methods of evaluating usability has already been established in other domains. Further research is needed to find ways to employ these methods, such as eye tracking and remote monitoring in the development of eHealth applications. There are also other automated methods that may potentially be useful, such as electroencephalogram (EEG) headsets [37], which can record brainwave patterns associated with attention, interest, relaxation and other mental states whilst evaluating the app. If validated, this could be useful objective measure of app usability. Eye-tracking is another automated method that was cited in a previous review [8] that is potentially useful in evaluating the usability of Ehealth applications. At least one recent study has already started exploring the validity of eye-tracking in the evaluation of Ehealth applications [38].

Validation of sample size estimates would also contribute to more efficient use of resources in usability investigations. In the selected studies, only $25.95 \%$ cited a reference to justify their sample size. Often, only one method such as questionnaires, was used in the evaluation because of finite resources when the investigators want as large a sample as possible to improve validity. However, a large sample size is wasteful if a smaller sample size is sufficient to ensure validity. The smaller sample size could then be used with more cycles of testing, giving a more complete picture of what is needed to improve the usability of the app.

We also found that the manner of reporting user experience evaluation lacks uniformity, making it difficult to compare results. Some studies merely reported that their participants found the applications to be usable, whereas others reported the scores using validated instruments such as the System Usability Scale. The use of many types of questionnaires, some validated and some that were not validated, also made the comparison of results across studies very difficult.

As new types of health apps and new platforms for them are developed, then new methods of usability testing will need to evolve. For example, there has been a growth in the number of health apps developed for the smart speaker platform, such as the Amazon Echo and Google Home product line [39-41]. These apps, which use voice recognition, will have to use different methods to assess their usability. Further research needs to be done to develop usability testing methods for these platforms.

As noted earlier, most digital health applications are developed in the commercial sector rather than the academe, and that this sector rarely publishes in the academic literature. There is scope for further research into the methods of usability evaluation employed by eHealth developers in the commercial sector, using the methodologies found in the work of Eshet, who conducted interviews and surveys amongst IT professionals $[42,43]$. This new research would give a more complete picture of the methods used by eHealth developers for usability evaluation.

Commissioning bodies will be looking for evidence of effectiveness for digital health applications, and in response to the need for guidance, the National Institute for Health and Care Excellence (NICE) has published an Evidence Standards Framework for Digital Health Technologies (DHT) [44]. In the framework, user experience falls under the Acceptability portion for the Tier 1 level of evidence, where the minimum accepted level of evidence is being able to show relevant user involvement in the design, development and testing of the DHT as well as user satisfaction data, to a "best practice standard" of publicly available or published evidence of user involvement and user satisfaction. Thus, there will now be an onus on DHT developers to publish the results of their user experience evaluations, as they will be required to submit these as evidence when seeking to have their

Implications

The findings of this scoping review provide an update to the field and highlight the fact that while the number of available digital health applications has greatly increased, the proportion of these applications that report the results of their usability experience research in peer reviewed publications has not increased and has in fact decreased slightly. The methods that were used three years ago are still being used but there are obvious areas 
for further research: to both evaluate these approaches and/or to develop / test new approaches to usability evaluation. Patient participation groups would also want to know how involved patients are in the development and testing process of eHealth apps. Researchers who are looking for new areas to do usability research in will find new opportunities in sample size validation, and in evolving ways of testing new platforms for eHealth apps such as smart speakers and virtual reality. Finally, as this was a scoping review of usability testing methods in eHealth applications, there is room to further qualitatively explore the underlying themes revealed by user experience studies of digital health technologies, as well as scope for further quantitative work.

Limitations

One limitation of this review is the exclusion of articles not published in English. This is common in scoping reviews, but we may have missed some relevant papers, especially for apps that are not published in English. We noted however, that some foreign language apps, such as in Korean, Chinese, Spanish, etc., were included in the review. Another limitation is that a lot of the apps in the app stores are not developed by academics and their developers do not report the findings of their usability tests in the academic literature. We would like to see in the future more information sharing from the developers of eHealth applications with regards to their usability testing methods, without necessarily giving away trade secrets. As mentioned previously, mixed-methods research with eHealth developers $[42,43]$ may be useful in this regard.

\section{Conclusions}

This scoping review gives a descriptive map of the literature on the methods used for usability testing of eHealth apps since 2014. This is a rapidly expanding area, seeing a tenfold increase in the number of eHealth apps in just three years, and yet the number of articles has not expanded accordingly, and the proportion of published literature has even decreased. There are still gaps in the research that need to be addressed, especially as commissioning bodies who wish to deploy digital health applications as part of services are demanding evaluation evidence as a prerequisite to deployment. As eHealth becomes increasingly relied upon to help deliver efficient and effective health care, there must be assurance that eHealth apps are usable, effective and fit for purpose. 


\section{Authors' contributions}

The search strategy was developed by IM and approved by $\mathrm{CN}$ and AC. IM performed the data extraction under the supervision of $\mathrm{CN}$ and $\mathrm{AC}$.

\section{Acknowledgements}

This research was supported by the eHealth Productivity and Innovation in Cornwall and the Isles of Scilly (EPIC) Project (Director: Professor Ray Jones), which is partially funded by the European Regional Development fund. The authors would like to acknowledge the support of the EPIC Project Team.

\section{Statement on conflicts of interest}

The authors declare that they have no conflicts of interest in the research.

\section{Summary table}

What was already known about the topic:

- The number of eHealth applications has seen rapid growth in the past three years. Only a small proportion of these publish the results of usability studies in the literature.

- The most frequently used methods of usability evaluation are quantitative methods such as questionnaires.

What this research adds to our knowledge:

- Despite the rapid growth in the number of eHealth applications, the proportion of new applications that publish usability evaluations has become smaller. Research needs to be conducted among eHealth application developers who do not publish their results in the literature, to investigate whether they employ formal usability testing methods, and the types of methods used.

- Questionnaires are still the most often used method of evaluating the usability of eHealth applications.

- There is little use of automated methods of objectively evaluating usability, such as eye-tracking.

- Further research is needed to evolve rapid methods of evaluating usability of eHealth applications in a robust manner, to meet the needs of commissioning bodies and improve adoption of eHealth.

\section{References}

[1] N.H.S. England, Five year forward view. October 2014, Available Online via Http//Www. England. Nhs. Uk/Wpcontent/Uploads/2014/10/5yfv-Web. Pdf. (2016).

[2] NHS England, The NHS long term plan, (2019). https://www.longtermplan.nhs.uk/.

[3] Research 2 Guidance, mHealth App Economics 2017, 2017. www.research2guidance.com (accessed June 10, 2018).

[4] T. Greenhalgh, J. Wherton, C. Papoutsi, J. Lynch, G. Hughes, C. A'Court, S. Hinder, N. Fahy, R. Procter, S. Shaw, Beyond adoption: A new framework for theorizing and evaluating nonadoption, abandonment, and challenges to the scale-up, spread, and sustainability of health and care technologies, J. Med. Internet Res. 19 (2017) e367. doi:10.2196/jmir.8775.

[5] R.B. Jones, E.J. Ashurst, T. Trappes-Lomax, Searching for a sustainable process of service user and health professional online discussions to facilitate the implementation of e-health, Health Informatics J. 22 (2016) 948-961. doi:10.1177/1460458215599024. 
[6] M. van Limburg, J.E.W.C. van Gemert-Pijnen, N. Nijland, H.C. Ossebaard, R.M.G. Hendrix, E.R. Seydel, Why business modeling is crucial in the development of eHealth technologies., J. Med. Internet Res. 13 (2011) e124. doi:10.2196/jmir.1674.

[7] J. Broderick, T. Devine, E. Langhans, A.J. Lemerise, S. Lier, L. Harris, Designing health literate mobile apps, Institute of Medicine of the National Academies, 2014.

[8] B.C. Zapata, J.L. Fernandez-Aleman, A. Idri, A. Toval, Empirical studies on usability of mHealth apps: a systematic literature review., J. Med. Syst. 39 (2015) 1. doi:10.1007/s10916-014-0182-2.

[9] NHS England, Health Developer Network Digital Assessment Questions - Beta - Health Developer Network, (n.d.). https://developer.nhs.uk/digital-tools/daq/ (accessed July 5, 2018).

[10] MHRA, Human Factors and Usability Engineering - Guidance for Medical Devices Including Drugdevice Combination Products., Med. Healthc. Prod. Regul. Agency. (2017) 1-30.

https://www.gov.uk/government/uploads/system/uploads/attachment_data/file/645862/

HumanFactors_Medical-Devices_v1.0.pdf.

[11] ORCHA, About, (n.d.). https://www.orcha.co.uk/about/ (accessed July 5, 2018).

[12] Our Mobile Health, App Library - www.ourmobilehealth.com, (n.d.).

https://www.ourmobilehealth.com/app-library.html (accessed July 6, 2018).

[13] A. Dix, Human-computer interaction, in: Encycl. Database Syst., Springer, 2009: pp. 1327-1331.

[14] W. 3rd Brown, P.-Y.Y. Yen, M. Rojas, R. Schnall, Assessment of the Health IT Usability Evaluation Model (Health-ITUEM) for evaluating mobile health (mHealth) technology, J. Biomed. Inform. 46 (2013) 1080-1087. doi:10.1016/j.jbi.2013.08.001.

[15] I.S.O. DIS, 9241-210: 2010, Ergon. Hum. Syst. Interact. 210 (2009).

[16] M. Jaspers, L. Peute, ... A.L.-S. in health, undefined 2008, Pre-post evaluation of physicians' satisfaction with a redesigned electronic medical record system, Books.Google.Com. (n.d.). https://books.google.com/books? $\mathrm{hl}=$ en\&lr=\&id=krj78Gs4njkC\&oi=fnd\&pg=PA303\&ots=DxlB33D9hy\&sig=XglNCqlg9jDOhnHssfz78 FGV5cw (accessed February 1, 2019).

[17] L.A. HURYK, Factors influencing nurses' attitudes towards healthcare information technology, J. Nurs. Manag. 18 (2010) 606-612. doi:10.1111/j.1365-2834.2010.01084.x.

[18] H.L. Bleich, W. V. Slack, Reflections on electronic medical records: When doctors will use them and when they will not, Int. J. Med. Inform. 79 (2010) 1-4. doi:10.1016/J.IJMEDINF.2009.10.002.

[19] M. Peters, C. Godfrey, P. McInerney, C. Soares, H. Khalil, D. Parker, The Joanna Briggs Institute reviewers' manual 2015: methodology for JBI scoping reviews, (2015).

[20] B. Kitchenham, R. Pretorius, D. Budgen, O.P. Brereton, M. Turner, M. Niazi, S. Linkman, Systematic literature reviews in software engineering-A tertiary study, Inf. Softw. Technol. 52 (2010) 792-805. doi:10.1016/j.infsof.2010.03.006.

[21] C. Newman, Meeting Tier 1 of NICE standards for eHealth with clinical User Experience (UX) research, (n.d.). https://medium.com/@craig.newman/meeting-tier-1-of-nice-standards-for-ehealth-withclinical-user-experience-ux-research-2b832978fd6f (accessed January 31, 2019).

[22] R. Harte, L. Glynn, A. Rodriguez-Molinero, P.M. Baker, T. Scharf, L.R. Quinlan, G. OLaighin, A Human-Centered Design Methodology to Enhance the Usability, Human Factors, and User Experience of Connected Health Systems: A Three-Phase Methodology., JMIR Hum. Factors. 4 (2017) e8. doi:10.2196/humanfactors.5443.

[23] R. Harte, L.R. Quinlan, L. Glynn, A. Rodriguez-Molinero, P.M. Baker, T. Scharf, G. OLaighin, HumanCentered Design Study: Enhancing the Usability of a Mobile Phone App in an Integrated Falls Risk Detection System for Use by Older Adult Users., JMIR MHealth UHealth. 5 (2017) e71. doi:10.2196/mhealth.7046.

[24] M.R. Fu, D. Axelrod, A.A. Guth, K. Rampertaap, N. El-Shammaa, K. Hiotis, J. Scagliola, G. Yu, Y. 
Wang, mHealth self-care interventions: managing symptoms following breast cancer treatment., MHealth. 2 (2016). doi:10.21037/mhealth.2016.07.03.

[25] A.L. Hartzler, A. Venkatakrishnan, S. Mohan, M. Silva, P. Lozano, J.D. Ralston, E. Ludman, D. Rosenberg, K.M. Newton, L. Nelson, P. Pirolli, Acceptabi[1] A.L. Hartzler, A. Venkatakrishnan, S. Mohan, M. Silva, P. Lozano, J.D. Ralston, E. Ludman, D. Rosenberg, K.M. Newton, L. Nelson, P. Pirolli, Acceptability of a team-based mobile health (mHealth) application for lifestyle self-management in in, Conf. Proc. ... Annu. Int. Conf. IEEE Eng. Med. Biol. Soc. IEEE Eng. Med. Biol. Soc. Annu. Conf. 2016 (2016) 3277-3281. doi:10.1109/EMBC.2016.7591428.

[26] A. Ledesma, M. Al-Musawi, H. Nieminen, Health figures: an open source JavaScript library for health data visualization., BMC Med. Informatics Decis. Mak. 16 (2016) 1-19. doi:10.1186/s12911-016-02756.

[27] A. Rothgangel, S. Braun, R. Smeets, A. Beurskens, Design and Development of a Telerehabilitation Platform for Patients With Phantom Limb Pain: A User-Centered Approach, JMIR Rehabil. Assist. Technol. 4 (2017) e2. doi:10.2196/rehab.6761.

[28] R. Schnall, M. Rojas, S. Bakken, W. Brown, A. Carballo-Dieguez, M. Carry, D. Gelaude, J.P. Mosley, J. Travers, A user-centered model for designing consumer mobile health (mHealth) applications (apps), J. Biomed. Inform. 60 (2016) 243-251. doi:10.1016/j.jbi.2016.02.002.

[29] C.D. Stein, X. Xiao, S. Levine, T.K.L. Schleyer, H. Hochheiser, T.P. Thyvalikakath, A prototype mobile application for triaging dental emergencies, J. Am. Dent. Assoc. 147 (2016) 782-791.e1. doi:10.1016/j.adaj.2016.03.021.

[30] A. de Souza Inacio, A. Savaris, J.M. Alves, A. von Wangenheim, GISTelemed: An online-based GIS approach to epidemiological analysis in telemedicine systems, in: 2016 38th Annu. Int. Conf. IEEE Eng. Med. Biol. Soc., IEEE, 2016: pp. 5376-5379. doi:10.1109/EMBC.2016.7591942.

[31] J.M. Alves, A. Savaris, C.G. Von Wangenheim, A. Von Wangenheim, Software quality evaluation of the laboratory information system used in the Santa Catarina state integrated telemedicine and telehealth system, in: Proc. - IEEE Symp. Comput. Med. Syst., IEEE, 2016: pp. 76-81. doi:10.1109/CBMS.2016.51.

[32] J.M. Alves, D.B.L. Albino, M.C. Resener, M. Zannin, A. Savaris, C.G. Von Wangenheim, A. Von Wangenheim, Quality evaluation of poison control information systems: A case study of the DATATOX system, in: Proc. - IEEE Symp. Comput. Med. Syst., IEEE, 2016: pp. 30-35. doi:10.1109/CBMS.2016.53.

[33] X. Ferre, E. Villalba, H. Julio, H. Zhu, Extending Mobile App Analytics for Usability Test Logging, in: Springer, Cham, 2017: pp. 114-131. doi:10.1007/978-3-319-67687-6_9.

[34] T.O. Andersen, J.P. Bansler, F. Kensing, J. Moll, T. Mønsted, K.D. Nielsen, O.W. Nielsen, H.H. Petersen, J.H. Svendsen, Aligning Concerns in Telecare: Three Concepts to Guide the Design of Patient-Centred E-Health, Comput. Support. Coop. Work CSCW An Int. J. 27 (2018) 1181-1214. doi:10.1007/s10606-018-9309-1.

[35] M. Campbell, R. Fitzpatrick, A. Haines, A.L. Kinmonth, P. Sandercock, D. Spiegelhalter, P. Tyrer, Framework for design and evaluation of complex interventions to improve health, BMJ Br. Med. J. 321 (2000) 694-696. http://www.ncbi.nlm.nih.gov/pmc/articles/PMC1118564/.

[36] M. Neuhaus, G.N. Healy, B.S. Fjeldsoe, S. Lawler, N. Owen, D.W. Dunstan, A.D. LaMontagne, E.G. Eakin, Iterative development of Stand Up Australia: a multi-component intervention to reduce workplace sitting, Int. J. Behav. Nutr. Phys. Act. 11 (2014) 21. doi:10.1186/1479-5868-11-21.

[37] S. Wang, J. Gwizdka, W.A. Chaovalitwongse, Using Wireless EEG Signals to Assess Memory Workload in the n-Back Task, IEEE Trans. Human-Machine Syst. 46 (2016) 424-435. doi:10.1109/THMS.2015.2476818.

[38] C. Schaarup, G. Hartvigsen, L.B. Larsen, Z.-H. Tan, E. Arsand, O.K. Hejlesen, Assessing the Potential Use of Eye-Tracking Triangulation for Evaluating the Usability of an Online Diabetes Exercise System., Stud. Health Technol. Inform. 216 (2015) 84-88.

[39] A. Reis, D. Paulino, H. Paredes, J. Barroso, Using intelligent personal assistants to strengthen the 
elderlies' social bonds: A preliminary evaluation of amazon alexa, google assistant, microsoft cortana, and apple siri, in: Lect. Notes Comput. Sci. (Including Subser. Lect. Notes Artif. Intell. Lect. Notes Bioinformatics), Springer, Cham, 2017: pp. 593-602. doi:10.1007/978-3-319-58700-4_48.

[40] M.R. Ebling, Can Cognitive Assistants Disappear?, IEEE Pervasive Comput. 15 (2016) 4-6. doi:10.1109/MPRV.2016.41.

[41] C. Franzese, M. Coyne, The promise of voice: Connecting drug delivery through voice-activated technology, ONdrugDelivery. 2017 (2017) 34-37.

[42] E. Eshet, H. Bouwman, Addressing the Context of Use in Mobile Computing: A Survey on the State of the Practice, Interact. Comput. 27 (2012) 392-412. doi:10.1093/iwc/iwu002.

[43] E. Eshet, H. Bouwman, Context of Use: The Final Frontier in the Practice of User-Centered Design?, Interact. Comput. 29 (2017) 368-390. doi:10.1093/iwc/iww030.

[44] NATIONAL INSTITUTE FOR HEALTH AND CARE EXCELLENCE, Evidence Standards Framework for Digital Health Technologies-December 2018, 2018.

https://www.nice.org.uk/Media/Default/About/what-we-do/our-programmes/evidence-standardsframework/digital-evidence-standards-framework.pdf (accessed February 5, 2019). 
Appendices

Table A1: Description of Included Studies (Alphabetically by Author name)

$\begin{array}{lllll}\text { Author Year Country Health Area } & \begin{array}{l}\text { Sample } \\ \text { Size (n) }\end{array} & \text { Methods } & \begin{array}{l}\text { Primary } \\ \text { User }\end{array}\end{array} \quad$ Title

Abbass-Dick 2017 CA Child Health 149 Questionnaire Dua

The Development and piloting of an eHealth breastfeeding resource targeting fathers and partners as co-parents

ABIDI 2017 CA Diabetes $22 \quad$ Think Aloud Dual

A Digital Framework to Support Providers and Patients in Diabetes Related Behavior Modification..."Informatics for Health," Manchester, UK, April 2017

Agnisarman 2017 US Telemedicine 5

Heuristic

Clinician

Toward a More Usable Home-Based Video

Telemedicine System: A Heuristic Evaluation of the Clinician User Interfaces of Home-Based Video Telemedicine Systems.

\begin{tabular}{|c|c|c|c|c|c|c|c|}
\hline Ahn & 2016 & KR & CPR & 30 & Questionnaire & Dual & $\begin{array}{l}\text { Evaluation of Smartphone } \\
\text { Applications for } \\
\text { Cardiopulmonary } \\
\text { Resuscitation Training in } \\
\text { South Korea }\end{array}$ \\
\hline Alanzi & 2016 & SA & Diabetes & 33 & Questionnaire & Patient & $\begin{array}{l}\text { Design and Usability } \\
\text { Evaluation of Social } \\
\text { Mobile Diabetes } \\
\text { Management System in the } \\
\text { Gulf Region. }\end{array}$ \\
\hline Alnosayan & 2017 & US & CVD & 8 & $\begin{array}{l}\text { Questionnaire } \\
\text { Focus Group } \\
\text { Interview }\end{array}$ & Dual & $\begin{array}{l}\text { Design and Usability of a } \\
\text { Heart Failure mHealth } \\
\text { System: A Pilot Study }\end{array}$ \\
\hline Alves & 2016 & $\mathrm{BR}$ & Telemedicine & 68 & Questionnaire & Clinician & $\begin{array}{l}\text { Software quality } \\
\text { evaluation of the } \\
\text { laboratory information } \\
\text { system used in the Santa } \\
\text { Catarina state integrated } \\
\text { telemedicine and telehealth } \\
\text { system }\end{array}$ \\
\hline Alves & 2016 & $\mathrm{BR}$ & Telemedicine & 48 & Questionnaire & Clinician & $\begin{array}{l}\text { Quality evaluation of } \\
\text { poison control information }\end{array}$ \\
\hline
\end{tabular}




\begin{tabular}{|c|c|c|c|c|c|c|c|}
\hline & & & & & & & $\begin{array}{l}\text { systems: A case study of } \\
\text { the DATATOX system }\end{array}$ \\
\hline Armin & 2017 & US & Smoking & 6 & $\begin{array}{l}\text { Think Aloud } \\
\text { Questionnaire } \\
\text { Focus Group }\end{array}$ & Patient & $\begin{array}{l}\text { Development of a Multi- } \\
\text { Behavioral mHealth App } \\
\text { for Women Smokers }\end{array}$ \\
\hline Arvidsson & 2016 & $\mathrm{SE}$ & Cancer & 17 & $\begin{array}{l}\text { Think Aloud } \\
\text { Interview }\end{array}$ & Dual & $\begin{array}{l}\text { Redesign and Validation of } \\
\text { Sisom, an Interactive } \\
\text { Assessment and } \\
\text { Communication Tool for } \\
\text { Children With Cancer. }\end{array}$ \\
\hline Athilingam & 2016 & US & CVD & 37 & $\begin{array}{l}\text { Heuristic } \\
\text { Questionnaire } \\
\text { Task } \\
\text { Completion }\end{array}$ & Dual & $\begin{array}{l}\text { Features and usability } \\
\text { assessment of a patient- } \\
\text { centered mobile } \\
\text { application (HeartMapp) } \\
\text { for self-management of } \\
\text { heart failure }\end{array}$ \\
\hline Attwood & 2017 & UK & Alcohol & 21 & $\begin{array}{l}\text { Interview Task } \\
\text { Completion }\end{array}$ & Patient & $\begin{array}{l}\text { Using a mobile health } \\
\text { application to reduce } \\
\text { alcohol consumption: a } \\
\text { mixed-methods evaluation } \\
\text { of the drinkaware track } \backslash \& \\
\text { calculate units application }\end{array}$ \\
\hline Birney & 2016 & US & $\begin{array}{l}\text { Mental } \\
\text { Health }\end{array}$ & 150 & $\begin{array}{l}\text { Questionnaire } \\
\text { Task } \\
\text { Completion }\end{array}$ & Patient & $\begin{array}{l}\text { MoodHacker Mobile Web } \\
\text { App With Email for Adults } \\
\text { to Self-Manage Mild-to- } \\
\text { Moderate Depression: } \\
\text { Randomized Controlled } \\
\text { Trial. }\end{array}$ \\
\hline Bolle & 2016 & NL & Cancer & 23 & $\begin{array}{l}\text { Think Aloud } \\
\text { Interview }\end{array}$ & Patient & $\begin{array}{l}\text { Older Cancer Patients' } \\
\text { User Experiences With } \\
\text { Web-Based Health } \\
\text { Information Tools: A } \\
\text { Think-Aloud Study }\end{array}$ \\
\hline BORYCKI & 2017 & $\mathrm{CA}$ & EHR & 4 & $\begin{array}{l}\text { Think Aloud } \\
\text { Interview }\end{array}$ & Clinician & $\begin{array}{l}\text { Isolating the Effects of a } \\
\text { Mobile Phone on the } \\
\text { Usability and Safety of } \\
\text { eHealth Software } \\
\text { Applications...ITCH } 2017\end{array}$ \\
\hline Boudreaux & 2017 & US & $\begin{array}{l}\text { Mental } \\
\text { Health }\end{array}$ & 30 & $\begin{array}{l}\text { Think Aloud } \\
\text { Questionnaire } \\
\text { Interview Task } \\
\text { Completion }\end{array}$ & Patient & $\begin{array}{l}\text { Computer Administered } \\
\text { Safety Planning for } \\
\text { Individuals at Risk for } \\
\text { Suicide: Development and } \\
\text { Usability Testing }\end{array}$ \\
\hline Brinkel & 2017 & $\mathrm{GH}$ & Child Health & 37 & $\begin{array}{l}\text { Questionnaire } \\
\text { Focus Group }\end{array}$ & Patient & $\begin{array}{l}\text { Mobile phone-based } \\
\text { interactive voice response } \\
\text { as a tool for improving } \\
\text { access to healthcare in }\end{array}$ \\
\hline
\end{tabular}




\begin{tabular}{|c|c|c|c|c|c|c|c|}
\hline & & & & & & & $\begin{array}{l}\text { remote areas in Ghana - an } \\
\text { evaluation of user } \\
\text { experiences }\end{array}$ \\
\hline Cai & 2017 & UK & Arthritis & 13 & $\begin{array}{l}\text { Questionnaire } \\
\text { Interview }\end{array}$ & Patient & $\begin{array}{l}\text { Developing and Evaluating } \\
\text { JIApp: Acceptability and } \\
\text { Usability of a Smartphone } \\
\text { App System to Improve } \\
\text { Self-Management in } \\
\text { Young People With } \\
\text { Juvenile Idiopathic } \\
\text { Arthritis }\end{array}$ \\
\hline Carrera & 2016 & ES & CVD & 20 & $\begin{array}{l}\text { Questionnaire } \\
\text { Task } \\
\text { Completion }\end{array}$ & Patient & $\begin{array}{l}\text { BPcontrol. A Mobile App } \\
\text { to Monitor Hypertensive } \\
\text { Patients. }\end{array}$ \\
\hline Carter & 2015 & UK & Nutrition & 117 & $\begin{array}{l}\text { Questionnaire } \\
\text { Focus Group } \\
\text { Task } \\
\text { Completion }\end{array}$ & Patient & $\begin{array}{l}\text { Development of a UK } \\
\text { Online 24-h Dietary } \\
\text { Assessment Tool: } \\
\text { myfood24. }\end{array}$ \\
\hline Chen & 2015 & $\mathrm{AU}$ & Nutrition & 2 & Questionnaire & Patient & $\begin{array}{l}\text { The Most Popular } \\
\text { Smartphone Apps for } \\
\text { Weight Loss: A Quality } \\
\text { Assessment. }\end{array}$ \\
\hline Crane & 2017 & UK & Alcohol & 24 & $\begin{array}{l}\text { Think Aloud } \\
\text { Interview Task } \\
\text { Completion }\end{array}$ & Patient & $\begin{array}{l}\text { Factors Influencing } \\
\text { Usability of a Smartphone } \\
\text { App to Reduce Excessive } \\
\text { Alcohol Consumption: } \\
\text { Think Aloud and Interview } \\
\text { Studies. }\end{array}$ \\
\hline Dasgupta & 2016 & US & Aging & 16 & $\begin{array}{l}\text { Questionnaire } \\
\text { Task } \\
\text { Completion }\end{array}$ & Patient & $\begin{array}{l}\text { eSeniorCare: Technology } \\
\text { for Promoting Well-Being } \\
\text { of Older Adults in } \\
\text { Independent Living } \\
\text { Facilities }\end{array}$ \\
\hline De la Vega & 2018 & ES & Fibromyalgia & 25 & $\begin{array}{l}\text { Think Aloud } \\
\text { Interview Task } \\
\text { Completion }\end{array}$ & Patient & $\begin{array}{l}\text { Fibroline: A mobile app } \\
\text { for improving the quality } \\
\text { of life of young people } \\
\text { with fibromyalgia. }\end{array}$ \\
\hline $\begin{array}{l}\{\text { De Souza } \\
\text { Inacio }\}\end{array}$ & 2016 & $\mathrm{BR}$ & Telemedicine & 26 & $\begin{array}{l}\text { Questionnaire } \\
\text { Interview }\end{array}$ & Clinician & $\begin{array}{l}\text { GISTelemed: An online- } \\
\text { based GIS approach to } \\
\text { epidemiological analysis in } \\
\text { telemedicine systems }\end{array}$ \\
\hline Desteghe & 2017 & $\mathrm{BE}$ & CVD & 15 & $\begin{array}{l}\text { Questionnaire } \\
\text { Focus Group } \\
\text { Task } \\
\text { Completion }\end{array}$ & Patient & $\begin{array}{l}\text { The Health Buddies App } \\
\text { as a Novel Tool to } \\
\text { Improve Adherence and } \\
\text { Knowledge in Atrial } \\
\text { Fibrillation Patients: A }\end{array}$ \\
\hline
\end{tabular}


Pilot Study.

\begin{tabular}{|c|c|c|c|c|c|c|c|}
\hline Eapen & 2015 & $\mathrm{CA}$ & $\begin{array}{l}\text { Health Info } \\
\text { System }\end{array}$ & 77 & Questionnaire & Clinician & $\begin{array}{l}\text { Mobile Access to } \\
\text { ClinicalConnect: A User } \\
\text { Feedback Survey on } \\
\text { Usability, Productivity, } \\
\text { and Quality. }\end{array}$ \\
\hline $\begin{array}{l}\text { Eguiluz- } \\
\text { Perez }\end{array}$ & 2014 & ES & $\begin{array}{l}\text { Multiple } \\
\text { Sclerosis }\end{array}$ & 10 & Questionnaire & Dual & $\begin{array}{l}\text { Comprehensive verticality } \\
\text { analysis and web-based } \\
\text { rehabilitation system for } \\
\text { people with multiple } \\
\text { sclerosis with supervised } \\
\text { medical monitoring. }\end{array}$ \\
\hline Eiring & 2017 & NO & $\begin{array}{l}\text { Mental } \\
\text { Health }\end{array}$ & 78 & $\begin{array}{l}\text { Think Aloud } \\
\text { Questionnaire } \\
\text { Task } \\
\text { Completion }\end{array}$ & Dual & $\begin{array}{l}\text { The development and } \\
\text { feasibility of a personal } \\
\text { health-optimization system } \\
\text { for people with bipolar } \\
\text { disorder }\end{array}$ \\
\hline English & 2016 & UG & Child Health & 30 & $\begin{array}{l}\text { Questionnaire } \\
\text { Task } \\
\text { Completion }\end{array}$ & Clinician & $\begin{array}{l}\text { The PAediatric Risk } \\
\text { Assessment (PARA) } \\
\text { Mobile App to Reduce } \\
\text { Postdischarge Child } \\
\text { Mortality: Design, } \\
\text { Usability, and Feasibility } \\
\text { for Health Care Workers in } \\
\text { Uganda. }\end{array}$ \\
\hline Fairman & 2016 & US & Spina Bifida & 45 & $\begin{array}{l}\text { Think Aloud } \\
\text { Questionnaire } \\
\text { Interview Task } \\
\text { Completion }\end{array}$ & Dual & $\begin{array}{l}\text { Iterative Design and } \\
\text { Usability Testing of the } \\
\text { Imhere System for } \\
\text { Managing Chronic } \\
\text { Conditions and Disability. }\end{array}$ \\
\hline FALLAH & 2017 & IR & $\begin{array}{l}\text { Medication } \\
\text { adherence }\end{array}$ & 6 & Questionnaire & Dual & $\begin{array}{l}\text { A Medication Reminder } \\
\text { Mobile App: Does It Work } \\
\text { for Different Age Ranges. }\end{array}$ \\
\hline Ferreira & 2015 & $\begin{array}{l}\text { PT,NO,D } \\
\text { E }\end{array}$ & $\begin{array}{l}\text { Parkinson's } \\
\text { Disease }\end{array}$ & 11 & $\begin{array}{l}\text { Questionnaire } \\
\text { Interview Task } \\
\text { Completion }\end{array}$ & Patient & $\begin{array}{l}\text { Quantitative home-based } \\
\text { assessment of Parkinson's } \\
\text { symptoms: the SENSE- } \\
\text { PARK feasibility and } \\
\text { usability study. }\end{array}$ \\
\hline Ferron & 2017 & US & Smoking & 21 & $\begin{array}{l}\text { Think Aloud } \\
\text { Questionnaire } \\
\text { Interview }\end{array}$ & Patient & $\begin{array}{l}\text { Mobile Phone Apps for } \\
\text { Smoking Cessation: } \\
\text { Quality and Usability } \\
\text { Among Smokers With } \\
\text { Psychosis. }\end{array}$ \\
\hline Fiks & 2017 & US & Child Health & 135 & $\begin{array}{l}\text { Questionnaire } \\
\text { Task } \\
\text { Completion }\end{array}$ & Patient & $\begin{array}{l}\text { Usability, Acceptability, } \\
\text { and Impact of a Pediatric } \\
\text { Teledermatology Mobile }\end{array}$ \\
\hline
\end{tabular}




\begin{tabular}{|c|c|c|c|c|c|c|c|}
\hline & & & & & & & Health Application \\
\hline Fleming & 2017 & US & $\begin{array}{l}\text { Mental } \\
\text { Health }\end{array}$ & 9 & $\begin{array}{l}\text { Think Aloud } \\
\text { Interview }\end{array}$ & Patient & $\begin{array}{l}\text { Usability of a Culturally } \\
\text { Informed mHealth } \\
\text { Intervention for Symptoms } \\
\text { of Anxiety and } \\
\text { Depression: Feedback } \\
\text { From Young Sexual } \\
\text { Minority Men. }\end{array}$ \\
\hline $\mathrm{Fu}$ & 2016 & US & Cancer & 30 & $\begin{array}{l}\text { Heuristic } \\
\text { Think Aloud } \\
\text { Questionnaire } \\
\text { Task } \\
\text { Completion }\end{array}$ & Patient & $\begin{array}{l}\text { mHealth self-care } \\
\text { interventions: managing } \\
\text { symptoms following breast } \\
\text { cancer treatment }\end{array}$ \\
\hline Gao & 2017 & $\mathrm{CN}$ & Diabetes & 2 & Questionnaire & Patient & $\begin{array}{l}\text { Mobile application for } \\
\text { diabetes self-management } \\
\text { in China: Do they fit for } \\
\text { older adults? }\end{array}$ \\
\hline Georgsson & 2016 & US & Diabetes & 2 & $\begin{array}{l}\text { Heuristic Task } \\
\text { Completion }\end{array}$ & Patient & $\begin{array}{l}\text { Heuristic Evaluation of a } \\
\text { mHealth Diabetes Self- } \\
\text { Management System } \\
\text { Using Disease Specific } \\
\text { Patient Profiles. }\end{array}$ \\
\hline Georgsson & 2016 & US & Diabetes & 10 & $\begin{array}{l}\text { Think Aloud } \\
\text { Questionnaire } \\
\text { Interview }\end{array}$ & Patient & $\begin{array}{l}\text { An evaluation of patients' } \\
\text { experienced usability of a } \\
\text { diabetes mHealth system } \\
\text { using a multi-method } \\
\text { approach }\end{array}$ \\
\hline Georgsson & 2016 & US & Diabetes & 10 & $\begin{array}{l}\text { Questionnaire } \\
\text { Task } \\
\text { Completion }\end{array}$ & Patient & $\begin{array}{l}\text { Quantifying usability: an } \\
\text { evaluation of a diabetes } \\
\text { mHealth system on } \\
\text { effectiveness, efficiency, } \\
\text { and satisfaction metrics } \\
\text { with associated user } \\
\text { characteristics. }\end{array}$ \\
\hline Georgsson & 2016 & US & Diabetes & 3 & $\begin{array}{l}\text { Heuristic Task } \\
\text { Completion }\end{array}$ & Patient & $\begin{array}{l}\text { A Modified User-Oriented } \\
\text { Heuristic Evaluation of a } \\
\text { Mobile Health System for } \\
\text { Diabetes Self-management } \\
\text { Support }\end{array}$ \\
\hline Ginossar & 2017 & US & Cancer & 2 & Questionnaire & Patient & $\begin{array}{l}\text { Content, Usability, and } \\
\text { Utilization of Plain } \\
\text { Language in Breast Cancer } \\
\text { Mobile Phone Apps: A } \\
\text { Systematic Analysis. }\end{array}$ \\
\hline $\begin{array}{l}\{\text { Gomez } \\
\text { Qui }\{\backslash \\
\sim\{n\}\} \text { onez }\}\end{array}$ & 2016 & NL & Exercise & 373 & Questionnaire & Patient & $\begin{array}{l}\text { mHealth or eHealth? } \\
\text { Efficacy, Use, and } \\
\text { Appreciation of a Web- }\end{array}$ \\
\hline
\end{tabular}




\begin{tabular}{|c|c|c|c|c|c|c|c|}
\hline & & & & & & & $\begin{array}{l}\text { Based Computer-Tailored } \\
\text { Physical Activity } \\
\text { Intervention for Dutch } \\
\text { Adults: A Randomized } \\
\text { Controlled Trial. }\end{array}$ \\
\hline Groen & 2017 & NL & Cancer & 27 & $\begin{array}{l}\text { Questionnaire } \\
\text { Task } \\
\text { Completion }\end{array}$ & Patient & $\begin{array}{l}\text { Supporting Lung Cancer } \\
\text { Patients With an } \\
\text { Interactive Patient Portal: } \\
\text { Feasibility Study. }\end{array}$ \\
\hline Gunter & 2016 & US & $\begin{array}{l}\text { Postoperative } \\
\text { care }\end{array}$ & 9 & $\begin{array}{l}\text { Think Aloud } \\
\text { Questionnaire } \\
\text { Task } \\
\text { Completion }\end{array}$ & Patient & $\begin{array}{l}\text { Evaluating Patient } \\
\text { Usability of an Image- } \\
\text { Based Mobile Health } \\
\text { Platform for Postoperative } \\
\text { Wound Monitoring }\end{array}$ \\
\hline $\mathrm{Ha}$ & 2016 & BW & Tuberculosis & 2 & $\begin{array}{l}\text { Questionnaire } \\
\text { Task } \\
\text { Completion }\end{array}$ & Clinician & $\begin{array}{l}\text { Evaluation of a Mobile } \\
\text { Health Approach to } \\
\text { Tuberculosis Contact } \\
\text { Tracing in Botswana }\end{array}$ \\
\hline Halsall & 2017 & US & $\begin{array}{l}\text { Family } \\
\text { Planning }\end{array}$ & 69 & $\begin{array}{l}\text { Questionnaire } \\
\text { Task } \\
\text { Completion }\end{array}$ & Clinician & $\begin{array}{l}\text { Development of a Mobile } \\
\text { App for Family Planning } \\
\text { Providers }\end{array}$ \\
\hline Hangaard & 2016 & DK & $\begin{array}{l}\text { Chronic } \\
\text { Conditions }\end{array}$ & 7 & $\begin{array}{l}\text { Heuristic } \\
\text { Think Aloud }\end{array}$ & Clinician & $\begin{array}{l}\text { Participatory Heuristic } \\
\text { Evaluation of the Second } \\
\text { Iteration of the eWALL } \\
\text { Interface Application. }\end{array}$ \\
\hline Harte & 2017 & $\mathrm{IE}$ & $\begin{array}{l}\text { Fall } \\
\text { Prediction } \\
\text { Detection }\end{array}$ & 20 & $\begin{array}{l}\text { Heuristic } \\
\text { Think Aloud } \\
\text { Questionnaire } \\
\text { Task } \\
\text { Completion }\end{array}$ & Patient & $\begin{array}{l}\text { A Human-Centered Design } \\
\text { Methodology to Enhance } \\
\text { the Usability, Human } \\
\text { Factors, and User } \\
\text { Experience of Connected } \\
\text { Health Systems: A Three- } \\
\text { Phase Methodology. }\end{array}$ \\
\hline Harte & 2017 & IE & $\begin{array}{l}\text { Fall } \\
\text { Prediction } \\
\text { Detection }\end{array}$ & 20 & $\begin{array}{l}\text { Heuristic } \\
\text { Think Aloud } \\
\text { Questionnaire } \\
\text { Task } \\
\text { Completion }\end{array}$ & Patient & $\begin{array}{l}\text { Human-Centered Design } \\
\text { Study: Enhancing the } \\
\text { Usability of a Mobile } \\
\text { Phone App in an Integrated } \\
\text { Falls Risk Detection } \\
\text { System for Use by Older } \\
\text { Adult Users }\end{array}$ \\
\hline Hartzler & 2016 & US & Exercise & 15 & $\begin{array}{l}\text { Heuristic } \\
\text { Think Aloud } \\
\text { Questionnaire } \\
\text { Task } \\
\text { Completion }\end{array}$ & Patient & $\begin{array}{l}\text { Acceptability of a team- } \\
\text { based mobile health } \\
\text { (mHealth) application for } \\
\text { lifestyle self-management } \\
\text { in individuals with chronic } \\
\text { illnesses. }\end{array}$ \\
\hline Hassandra & 2017 & FI & Smoking & 25 & Questionnaire & Patient & $\begin{array}{l}\text { An mHealth App for } \\
\text { Supporting Quitters to }\end{array}$ \\
\hline
\end{tabular}




\begin{tabular}{|c|c|c|c|c|c|c|c|}
\hline & & & & & & & $\begin{array}{l}\text { Manage Cigarette Cravings } \\
\text { With Short Bouts of } \\
\text { Physical Activity: A } \\
\text { Randomized Pilot } \\
\text { Feasibility and } \\
\text { Acceptability Study. }\end{array}$ \\
\hline Hayashi & 2017 & JP & Dialysis & 7 & $\begin{array}{l}\text { Questionnaire } \\
\text { Task } \\
\text { Completion }\end{array}$ & Patient & $\begin{array}{l}\text { Testing the Feasibility and } \\
\text { Usability of a Novel } \\
\text { Smartphone-Based Self- } \\
\text { Management Support } \\
\text { System for Dialysis } \\
\text { Patients: A Pilot Study. }\end{array}$ \\
\hline Held & 2017 & $\mathrm{CH}, \mathrm{ES}$ & Stroke Rehab & 15 & $\begin{array}{l}\text { Questionnaire } \\
\text { Task } \\
\text { Completion }\end{array}$ & Patient & $\begin{array}{l}\text { Autonomous rehabilitation } \\
\text { at stroke patients home for } \\
\text { balance and gait: safety, } \\
\text { usability and compliance } \\
\text { of a virtual reality system. }\end{array}$ \\
\hline Himelhoch & 2017 & US & HIV & 19 & Questionnaire & Dual & $\begin{array}{l}\text { Pilot feasibility study of } \\
\text { Heart2HAART: a } \\
\text { smartphone application to } \\
\text { assist with adherence } \\
\text { among substance users } \\
\text { living with HIV }\end{array}$ \\
\hline Hoaas & 2016 & NO & COPD & 10 & $\begin{array}{l}\text { Think Aloud } \\
\text { Questionnaire } \\
\text { Focus Group } \\
\text { Task } \\
\text { Completion }\end{array}$ & Patient & $\begin{array}{l}\text { Adherence and factors } \\
\text { affecting satisfaction in } \\
\text { long-term telerehabilitation } \\
\text { for patients with chronic } \\
\text { obstructive pulmonary } \\
\text { disease: a mixed methods } \\
\text { study. }\end{array}$ \\
\hline $\begin{array}{l}\text { Hochstenbac } \\
\mathrm{h}\end{array}$ & 2016 & NL & Cancer & 11 & $\begin{array}{l}\text { Questionnaire } \\
\text { Focus Group } \\
\text { Interview Task } \\
\text { Completion }\end{array}$ & Dual & $\begin{array}{l}\text { Feasibility of a mobile and } \\
\text { web-based intervention to } \\
\text { support self-management } \\
\text { in outpatients with cancer } \\
\text { pain }\end{array}$ \\
\hline Hull & 2017 & US & Child Health & 60 & $\begin{array}{l}\text { Questionnaire } \\
\text { Interview Task } \\
\text { Completion }\end{array}$ & Patient & $\begin{array}{l}\text { A Smartphone App for } \\
\text { Families With Preschool- } \\
\text { Aged Children in a Public } \\
\text { Nutrition Program: } \\
\text { Prototype Development } \\
\text { and Beta-Testing. }\end{array}$ \\
\hline $\begin{array}{l}\text { Isakovi }\left\{\backslash^{\prime}\{c\}\right. \\
\}\end{array}$ & 2016 & SI & Diabetes & 10 & $\begin{array}{l}\text { Think Aloud } \\
\text { Questionnaire }\end{array}$ & Patient & $\begin{array}{l}\text { Usability Pitfalls of } \\
\text { Diabetes mHealth Apps for } \\
\text { the Elderly. }\end{array}$ \\
\hline Ithnin & 2017 & MY & $\begin{array}{l}\text { Adverse } \\
\text { Drug } \\
\text { Reactions }\end{array}$ & 26 & Questionnaire & Clinician & $\begin{array}{l}\text { Mobile App Design, } \\
\text { Development, and } \\
\text { Publication for Adverse }\end{array}$ \\
\hline
\end{tabular}




\begin{tabular}{|c|c|c|c|c|c|c|c|}
\hline & & & & & & & $\begin{array}{l}\text { Drug Reaction } \\
\text { Assessments of Causality, } \\
\text { Severity, and } \\
\text { Preventability }\end{array}$ \\
\hline Jeon & 2015 & $\mathrm{KR}$ & Nutrition & 10 & $\begin{array}{l}\text { Heuristic } \\
\text { Questionnaire }\end{array}$ & Patient & $\begin{array}{l}\text { Development of a } \\
\text { smartphone application for } \\
\text { clinical-guideline-based } \\
\text { obesity management. }\end{array}$ \\
\hline Jeon & 2016 & $\mathrm{KR}$ & $\begin{array}{l}\text { Metabolic } \\
\text { Syndrome }\end{array}$ & & $\begin{array}{l}\text { Heuristic } \\
\text { Questionnaire }\end{array}$ & Patient & $\begin{array}{l}\text { Mobile Apps Providing } \\
\text { Tailored Nursing } \\
\text { Interventions for Patients } \\
\text { with Metabolic Syndrome. }\end{array}$ \\
\hline $\mathrm{Ji}$ & 2015 & $\mathrm{CN}$ & Delirium & 102 & Questionnaire & Clinician & $\begin{array}{l}\text { Development and Usability } \\
\text { Evaluation of the Mobile } \\
\text { Delirium Assessment App } \\
\text { Based on Confusion } \\
\text { Assessment Method for } \\
\text { Intensive Care Unit } \\
\text { (CAM-ICU). }\end{array}$ \\
\hline Johnston & 2016 & $\mathrm{SE}$ & CVD & 174 & Questionnaire & Patient & $\begin{array}{l}\text { Effects of interactive } \\
\text { patient smartphone support } \\
\text { app on drug adherence and } \\
\text { lifestyle changes in } \\
\text { myocardial infarction } \\
\text { patients: A randomized } \\
\text { study }\end{array}$ \\
\hline Kelson & 2017 & $\mathrm{AU}$ & $\begin{array}{l}\text { Mental } \\
\text { Health }\end{array}$ & 40 & Questionnaire & Patient & $\begin{array}{l}\text { Development and } \\
\text { Evaluation of an Online } \\
\text { Acceptance and } \\
\text { Commitment Therapy } \\
\text { Program for Anxiety: } \\
\text { Phase I Iterative Design }\end{array}$ \\
\hline Kerr & 2017 & $\mathrm{AU}$ & Nutrition & 285 & Questionnaire & Patient & $\begin{array}{l}\text { BMI is Associated with the } \\
\text { Willingness to Record Diet } \\
\text { with a Mobile Food } \\
\text { Record among Adults } \\
\text { Participating in Dietary } \\
\text { Interventions }\end{array}$ \\
\hline Krishnamurti & 2017 & US & Pregnancy & 16 & $\begin{array}{l}\text { Questionnaire } \\
\text { Task } \\
\text { Completion }\end{array}$ & Patient & $\begin{array}{l}\text { Development and Testing } \\
\text { of the } \\
\text { MyHealthyPregnancy } \\
\text { App: A Behavioral } \\
\text { Decision Research-Based } \\
\text { Tool for Assessing and } \\
\text { Communicating Pregnancy } \\
\text { Risk }\end{array}$ \\
\hline Ledesma & 2016 & FI & Health Info & 14 & Heuristic & Clinician & Health figures: an open \\
\hline
\end{tabular}




\begin{tabular}{|c|c|c|c|c|c|c|c|}
\hline & & & System & & $\begin{array}{l}\text { Think Aloud } \\
\text { Questionnaire } \\
\text { Task } \\
\text { Completion }\end{array}$ & & $\begin{array}{l}\text { source JavaScript library } \\
\text { for health data } \\
\text { visualization }\end{array}$ \\
\hline Lilholt & 2015 & DK & Telemedicine & 5 & Heuristic & Clinician & $\begin{array}{l}\text { Heuristic evaluation of a } \\
\text { telehealth system from the } \\
\text { Danish TeleCare North } \\
\text { Trial }\end{array}$ \\
\hline Lim & 2015 & ZA & Pregnancy & 37 & Questionnaire & Clinician & $\begin{array}{l}\text { Usability and Feasibility of } \\
\text { PIERS on the Move: An } \\
\text { mHealth App for Pre- } \\
\text { Eclampsia Triage. }\end{array}$ \\
\hline Liu & 2016 & $\mathrm{AU}$ & $\begin{array}{l}\text { Medical } \\
\text { Education }\end{array}$ & 8 & Questionnaire & Clinician & $\begin{array}{l}\text { EQClinic: a platform for } \\
\text { learning communication } \\
\text { skills in clinical } \\
\text { consultations. }\end{array}$ \\
\hline Lodhia & 2016 & $\mathrm{KE}$ & $\begin{array}{l}\text { Ophthalmolo } \\
\text { gy }\end{array}$ & 32 & Interview & Dual & $\begin{array}{l}\text { Acceptability, Usability, } \\
\text { and Views on Deployment } \\
\text { of Peek, a Mobile Phone } \\
\text { mHealth Intervention for } \\
\text { Eye Care in Kenya: } \\
\text { Qualitative Study }\end{array}$ \\
\hline Martinez & 2017 & $\mathrm{NO}$ & $\begin{array}{l}\text { Geolocation } \\
\text { Alarm }\end{array}$ & 11 & $\begin{array}{l}\text { Think Aloud } \\
\text { Questionnaire } \\
\text { Task } \\
\text { Completion }\end{array}$ & Patient & $\begin{array}{l}\text { Usability evaluation of a } \\
\text { geolocation technology: } \\
\text { Safemate }\end{array}$ \\
\hline McClellan & 2016 & US & Cancer & 1 & Heuristic & Patient & $\begin{array}{l}\text { Designing an Educational } \\
\text { Website to Improve } \\
\text { Quality of Supportive } \\
\text { Oncology Care for Women } \\
\text { with Ovarian Cancer: An } \\
\text { Expert Usability Review } \\
\text { and Analysis. }\end{array}$ \\
\hline Miller & 2017 & US & Cancer & 450 & $\begin{array}{l}\text { Think Aloud } \\
\text { Questionnaire } \\
\text { Task } \\
\text { Completion }\end{array}$ & Patient & $\begin{array}{l}\text { Usability of a Novel } \\
\text { Mobile Health iPad App } \\
\text { by Vulnerable Populations. }\end{array}$ \\
\hline Milward & 2017 & UK & Alcohol & 20 & Focus Group & Patient & $\begin{array}{l}\text { Usability Testing of the } \\
\text { BRANCH Smartphone } \\
\text { App Designed to Reduce } \\
\text { Harmful Drinking in } \\
\text { Young Adults. }\end{array}$ \\
\hline Mistler & 2017 & US & $\begin{array}{l}\text { Metabolic } \\
\text { Syndrome }\end{array}$ & 12 & $\begin{array}{l}\text { Questionnaire } \\
\text { Interview }\end{array}$ & Patient & $\begin{array}{l}\text { Mobile Mindfulness } \\
\text { Intervention on an Acute } \\
\text { Psychiatric Unit: } \\
\text { Feasibility and }\end{array}$ \\
\hline
\end{tabular}




\begin{tabular}{|c|c|c|c|c|c|c|c|}
\hline & & & & & & & Acceptability Study. \\
\hline Mohadis & 2016 & MY & Exercise & 8 & Think Aloud & Patient & $\begin{array}{l}\text { Designing persuasive } \\
\text { application to encourage } \\
\text { physical activity at } \\
\text { workplace among older } \\
\text { workers }\end{array}$ \\
\hline Mummah & 2016 & US & Nutrition & 8 & Questionnaire & Patient & $\begin{array}{l}\text { Mobile Technology for } \\
\text { Vegetable Consumption: A } \\
\text { Randomized Controlled } \\
\text { Pilot Study in Overweight } \\
\text { Adults. }\end{array}$ \\
\hline Narasimha & 2018 & US & Telemedicine & 40 & $\begin{array}{l}\text { Think Aloud } \\
\text { Questionnaire } \\
\text { Task } \\
\text { Completion }\end{array}$ & Patient & $\begin{array}{l}\text { Designing Home-Based } \\
\text { Telemedicine Systems for } \\
\text { the Geriatric Population: } \\
\text { An Empirical Study. }\end{array}$ \\
\hline $\begin{array}{l}\text { NARV }\left\{\backslash^{\prime}\{\mathrm{A}\right. \\
\}\} \mathrm{EZ}\end{array}$ & 2016 & $\mathrm{CO}$ & $\begin{array}{l}\text { Mental } \\
\text { Health }\end{array}$ & 59 & $\begin{array}{l}\text { Think Aloud } \\
\text { Questionnaire }\end{array}$ & Patient & $\begin{array}{l}\text { Human-Centered Design } \\
\text { of an mHealth App for the } \\
\text { Prevention of Burnout } \\
\text { Syndrome. }\end{array}$ \\
\hline Neville & 2016 & $\mathrm{CA}$ & SLE & 37 & $\begin{array}{l}\text { Questionnaire } \\
\text { Interview }\end{array}$ & Patient & $\begin{array}{l}\text { Development of the Lupus } \\
\text { Interactive Navigator as an } \\
\text { Empowering Web-Based } \\
\text { eHealth Tool to Facilitate } \\
\text { Lupus Management: Users } \\
\text { Perspectives on Usability } \\
\text { and Acceptability. }\end{array}$ \\
\hline Nitsch & 2016 & US & $\begin{array}{l}\text { Mental } \\
\text { Health }\end{array}$ & 9 & $\begin{array}{l}\text { Think Aloud } \\
\text { Questionnaire } \\
\text { Interview }\end{array}$ & Patient & $\begin{array}{l}\text { A Guided Online and } \\
\text { Mobile Self-Help Program } \\
\text { for Individuals With } \\
\text { Eating Disorders: An } \\
\text { Iterative Engagement and } \\
\text { Usability Study }\end{array}$ \\
\hline O'Malley & 2014 & IE & Nutrition & 10 & $\begin{array}{l}\text { Questionnaire } \\
\text { Task } \\
\text { Completion }\end{array}$ & Patient & $\begin{array}{l}\text { Exploring the usability of a } \\
\text { mobile app for adolescent } \\
\text { obesity management. }\end{array}$ \\
\hline Pande & 2017 & ID & Tuberculosis & 105 & Questionnaire & Clinician & $\begin{array}{l}\text { Evaluating clinicians' user } \\
\text { experience and } \\
\text { acceptability ofLearnTB, a } \\
\text { smartphone application for } \\
\text { tuberculosis in India. }\end{array}$ \\
\hline Park & 2017 & US & Nutrition & 20 & $\begin{array}{l}\text { Think Aloud } \\
\text { Questionnaire } \\
\text { Interview }\end{array}$ & Patient & $\begin{array}{l}\text { A Facebook-Based Obesity } \\
\text { Prevention Program for } \\
\text { Korean American } \\
\text { Adolescents: Usability } \\
\text { Evaluation }\end{array}$ \\
\hline Pereira- & 2017 & NL & Cancer & 92 & Questionnaire & Clinician & Rotterdam Prostate Cancer \\
\hline
\end{tabular}


Azevedo

$$
\text { Perez }
$$

2016 US

Nutrition

6

Pifarr $\{\backslash\{\mathrm{e}\}\} 2017$ ES

Smoking

31

Ponce

2016 US

Telemedicine 30

PRZYSUCH 2016 DE

EHR

23

A

\section{RADHAKRI 2016 US SHNAN}

$\begin{array}{llll}\text { Rajan } & 2016 \text { BR } & \begin{array}{l}\text { Health Info } \\ \text { System }\end{array} \\ & & & \\ & & & \\ \text { Ray } & 2017 & \text { AU,ID } & \begin{array}{l}\text { Elderly } \\ \text { Wellbeing }\end{array}\end{array}$

14

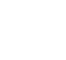

Rhyner $2016 \mathrm{CH} \quad$ Diabetes $19 \quad$ Questionnaire Patient

Focus Group Clinician
Task
Completion

Risk Calculator:

Development and Usability Testing of the Mobile

Phone App.
Questionnaire Patient

Think Aloud Patient
Interview

Questionnaire Patient

Questionnaire Patient
Adapting a weight management tool for Latina women: a usability study of the Veteran Health Administration's MOVE!23 tool.

TControl: A mobile app to follow up tobacco-quitting patients

Telemedicine with mobile devices and augmented reality for early postoperative care.

Questionnaire Clinician The Benefits of a Formative Evaluation for Developing a Highly Innovative Software: The Case of the HandoverEHR.

Perceptions of Older Adults with Heart Failure on Playing an Interactive Digital e-Health Game (IDEG) for Learning About Heart Failure (HF): Prototype Development and Usability Testing.

Understanding the barriers to successful adoption and use of a mobile health information system in a community health center in S $\sim$ ao Paulo, Brazil: a cohort study

Questionnaire Patient Interview

Tablet-Based Well-Being Check for the Elderly:

Development and Evaluation of Usability and Acceptability.

Carbohydrate Estimation by a Mobile Phone-Based System Versus SelfEstimations of Individuals With Type 1 Diabetes 


\begin{tabular}{|c|c|c|c|c|c|c|c|}
\hline & & & & & & & $\begin{array}{l}\text { Mellitus: A Comparative } \\
\text { Study }\end{array}$ \\
\hline Rollo & 2017 & AU & Nutrition & 90 & $\begin{array}{l}\text { Think Aloud } \\
\text { Questionnaire }\end{array}$ & Patient & $\begin{array}{l}\text { ServAR: An augmented } \\
\text { reality tool to guide the } \\
\text { serving of food }\end{array}$ \\
\hline Rothgangel & 2017 & $\mathrm{DE}$ & Telemedicine & 16 & $\begin{array}{l}\text { Heuristic } \\
\text { Questionnaire } \\
\text { Interview Task } \\
\text { Completion }\end{array}$ & Dual & $\begin{array}{l}\text { Design and Development } \\
\text { of a Telerehabilitation } \\
\text { Platform for Patients With } \\
\text { Phantom Limb Pain: A } \\
\text { User-Centered Approach }\end{array}$ \\
\hline Rothstein & 2016 & $\mathrm{GH}$ & Child Health & 14 & $\begin{array}{l}\text { Focus Group } \\
\text { Interview }\end{array}$ & Clinician & $\begin{array}{l}\text { Qualitative Assessment of } \\
\text { the Feasibility, Usability, } \\
\text { and Acceptability of a } \\
\text { Mobile Client Data App } \\
\text { for Community-Based } \\
\text { Maternal, Neonatal, and } \\
\text { Child Care in Rural Ghana }\end{array}$ \\
\hline Rotondi & 2015 & US & $\begin{array}{l}\text { Mental } \\
\text { Health }\end{array}$ & 38 & $\begin{array}{l}\text { Task } \\
\text { Completion }\end{array}$ & Patient & $\begin{array}{l}\text { Critical design elements of } \\
\text { e-health applications for } \\
\text { users with severe mental } \\
\text { illness: singular focus, } \\
\text { simple architecture, } \\
\text { prominent contents, } \\
\text { explicit navigation, and } \\
\text { inclusive hyperlinks. }\end{array}$ \\
\hline Rotondi & 2017 & US & $\begin{array}{l}\text { Mental } \\
\text { Health }\end{array}$ & 38 & $\begin{array}{l}\text { Task } \\
\text { Completion }\end{array}$ & Patient & $\begin{array}{l}\text { Designing eHealth } \\
\text { Applications to Reduce } \\
\text { Cognitive Effort for } \\
\text { Persons With Severe } \\
\text { Mental Illness: Page } \\
\text { Complexity, Navigation } \\
\text { Simplicity, and } \\
\text { Comprehensibility }\end{array}$ \\
\hline Sands & 2016 & $\mathrm{AU}$ & $\begin{array}{l}\text { Mental } \\
\text { Health }\end{array}$ & 10 & $\begin{array}{l}\text { Heuristic Task } \\
\text { Completion }\end{array}$ & Clinician & $\begin{array}{l}\text { Investigating the validity } \\
\text { and usability of an } \\
\text { interactive computer } \\
\text { programme for assessing } \\
\text { competence in telephone- } \\
\text { based mental health triage. }\end{array}$ \\
\hline Sarkar & 2016 & US & $\begin{array}{l}\text { Chronic } \\
\text { Conditions }\end{array}$ & 26 & $\begin{array}{l}\text { Think Aloud } \\
\text { Interview Task } \\
\text { Completion }\end{array}$ & Patient & $\begin{array}{l}\text { Usability of Commercially } \\
\text { Available Mobile } \\
\text { Applications for Diverse } \\
\text { Patients }\end{array}$ \\
\hline Schnall & 2016 & US & HIV & 15 & $\begin{array}{l}\text { Heuristic } \\
\text { Think Aloud } \\
\text { Questionnaire }\end{array}$ & Patient & $\begin{array}{l}\text { A user-centered model for } \\
\text { designing consumer } \\
\text { mobile health (mHealth) } \\
\text { applications (apps) }\end{array}$ \\
\hline
\end{tabular}




\begin{tabular}{|c|c|c|c|c|c|c|c|}
\hline Scott & 2017 & US & $\begin{array}{l}\text { Postoperative } \\
\text { care }\end{array}$ & 20 & $\begin{array}{l}\text { Questionnaire } \\
\text { Interview }\end{array}$ & Patient & $\begin{array}{l}\text { Mixed-Methods Analysis } \\
\text { of Factors Impacting Use } \\
\text { of a Postoperative mHealth } \\
\text { App }\end{array}$ \\
\hline Serwe & 2017 & US & Telemedicin & 4 & Questionnaire & Patient & $\begin{array}{l}\text { Feasibility of Using } \\
\text { Telehealth to Deliver the } \\
\text { "Powerful Tools for } \\
\text { Caregivers" Program }\end{array}$ \\
\hline Shellmer & 2016 & US & $\begin{array}{l}\text { Medication } \\
\text { adherence }\end{array}$ & 7 & $\begin{array}{l}\text { Questionnaire } \\
\text { Interview }\end{array}$ & Patient & $\begin{array}{l}\text { Development and field } \\
\text { testing of Teen Pocket } \\
\text { PATH \textregistered, a } \\
\text { mobile health application } \\
\text { to improve medication } \\
\text { adherence in adolescent } \\
\text { solid organ recipients }\end{array}$ \\
\hline Sheoran & 2016 & US & $\begin{array}{l}\text { Homeless } \\
\text { Youth }\end{array}$ & 6 & $\begin{array}{l}\text { Think Aloud } \\
\text { Focus Group } \\
\text { Interview }\end{array}$ & Patient & $\begin{array}{l}\text { YTH StreetConnect: } \\
\text { Development and Usability } \\
\text { of a Mobile App for } \\
\text { Homeless and Unstably } \\
\text { Housed Youth. }\end{array}$ \\
\hline Shochat & 2017 & IL & Brain Injury & 6 & Questionnaire & Patient & $\begin{array}{l}\text { Motion-based virtual } \\
\text { reality cognitive training } \\
\text { targeting executive } \\
\text { functions in acquired brain } \\
\text { injury community- } \\
\text { dwelling individuals: A } \\
\text { feasibility and initial } \\
\text { efficacy pilot }\end{array}$ \\
\hline Singh & 2017 & US & Head Injury & 29 & Questionnaire & Clinician & $\begin{array}{l}\text { Tablet-Based Patient- } \\
\text { Centered Decision Support } \\
\text { for Minor Head Injury in } \\
\text { the Emergency } \\
\text { Department: Pilot Study }\end{array}$ \\
\hline Smaradottir & 2016 & $\mathrm{NO}$ & Dementia & 7 & $\begin{array}{l}\text { Think Aloud } \\
\text { Questionnaire } \\
\text { Interview }\end{array}$ & Clinician & $\begin{array}{l}\text { The EU-project } \\
\text { United4Health: User- } \\
\text { centred design of an } \\
\text { information system for a } \\
\text { Norwegian telemedicine } \\
\text { service }\end{array}$ \\
\hline Smaradottir & 2015 & $\mathrm{NO}$ & Dementia & 5 & $\begin{array}{l}\text { Think Aloud } \\
\text { Questionnaire } \\
\text { Interview Task } \\
\text { Completion }\end{array}$ & Clinician & $\begin{array}{l}\text { eHealth-Extended Care } \\
\text { Coordination: } \\
\text { Development of a } \\
\text { Collaborative System for } \\
\text { Inter-municipal Dementia } \\
\text { Teams: A Research Project } \\
\text { with a User-Centered } \\
\text { Design Approach }\end{array}$ \\
\hline
\end{tabular}




\begin{tabular}{|c|c|c|c|c|c|c|c|}
\hline Solana & 2015 & ES & Telemedicine & 48 & Questionnaire & Dual & $\begin{array}{l}\text { Improving brain injury } \\
\text { cognitive rehabilitation by } \\
\text { personalized } \\
\text { telerehabilitation services: } \\
\text { Guttmann neuropersonal } \\
\text { trainer. }\end{array}$ \\
\hline $\begin{array}{l}\{\text { Steele } \\
\text { Gray }\}\end{array}$ & 2016 & $\mathrm{CA}$ & $\begin{array}{l}\text { Chronic } \\
\text { Conditions }\end{array}$ & 11 & $\begin{array}{l}\text { Focus Group } \\
\text { Interview Task } \\
\text { Completion }\end{array}$ & Dual & $\begin{array}{l}\text { The Electronic Patient } \\
\text { Reported Outcome Tool: } \\
\text { Testing Usability and } \\
\text { Feasibility of a Mobile } \\
\text { App and Portal to Support } \\
\text { Care for Patients With } \\
\text { Complex Chronic Disease } \\
\text { and Disability in Primary } \\
\text { Care Settings. }\end{array}$ \\
\hline Stein & 2016 & US & Dental & 20 & $\begin{array}{l}\text { Heuristic } \\
\text { Think Aloud } \\
\text { Questionnaire } \\
\text { Task } \\
\text { Completion }\end{array}$ & Dual & $\begin{array}{l}\text { A prototype mobile } \\
\text { application for triaging } \\
\text { dental emergencies }\end{array}$ \\
\hline $\mathrm{St}\{\backslash "\{\mathrm{u}\}\} \mathrm{tz}$ & 2017 & AT & $\begin{array}{l}\text { Physiotherap } \\
\mathrm{y}\end{array}$ & 5 & $\begin{array}{l}\text { Questionnaire } \\
\text { Task } \\
\text { Completion }\end{array}$ & Patient & $\begin{array}{l}\text { Mobile Phone-Supported } \\
\text { Physiotherapy for Frozen } \\
\text { Shoulder: Feasibility } \\
\text { Assessment Based on a } \\
\text { Usability Study. }\end{array}$ \\
\hline Sullivan & 2017 & US & HIV & 121 & $\begin{array}{l}\text { Questionnaire } \\
\text { Task } \\
\text { Completion }\end{array}$ & Patient & $\begin{array}{l}\text { Usability and Acceptability } \\
\text { of a Mobile } \\
\text { Comprehensive HIV } \\
\text { Prevention App for Men } \\
\text { Who Have Sex With Men: } \\
\text { A Pilot Study. }\end{array}$ \\
\hline Sun & 2017 & $\mathrm{CN}$ & Cancer & 25 & $\begin{array}{l}\text { Questionnaire } \\
\text { Task } \\
\text { Completion }\end{array}$ & Patient & $\begin{array}{l}\text { Development and Testing } \\
\text { of an Intelligent Pain } \\
\text { Management System } \\
\text { (IPMS) on Mobile Phones } \\
\text { Through a Randomized } \\
\text { Trial Among Chinese } \\
\text { Cancer Patients: A New } \\
\text { Approach in Cancer Pain } \\
\text { Management. }\end{array}$ \\
\hline Tay & 2017 & $\mathrm{AU}$ & Nutrition & 33 & $\begin{array}{l}\text { Questionnaire } \\
\text { Focus Group } \\
\text { Task } \\
\text { Completion }\end{array}$ & Patient & $\begin{array}{l}\text { Development and Testing } \\
\text { of a Mobile Phone App for } \\
\text { Self-Monitoring of } \\
\text { Calcium Intake in Young } \\
\text { Women }\end{array}$ \\
\hline $\begin{array}{l}\text { Thilakanatha } \\
\mathrm{n}\end{array}$ & 2016 & $\mathrm{AU}$ & $\begin{array}{l}\text { Health Info } \\
\text { System }\end{array}$ & 20 & $\begin{array}{l}\text { Think Aloud } \\
\text { Questionnaire } \\
\text { Task }\end{array}$ & Clinician & $\begin{array}{l}\text { Facilitating Secure Sharing } \\
\text { of Personal Health Data in }\end{array}$ \\
\hline
\end{tabular}




\begin{tabular}{|c|c|c|c|c|c|c|c|}
\hline & & & & & Completion & & the Cloud. \\
\hline Tielman & 2017 & NL & $\begin{array}{l}\text { Mental } \\
\text { Health }\end{array}$ & 4 & $\begin{array}{l}\text { Think Aloud } \\
\text { Questionnaire }\end{array}$ & Patient & $\begin{array}{l}\text { A Therapy System for } \\
\text { Post-Traumatic Stress } \\
\text { Disorder Using a Virtual } \\
\text { Agent and Virtual } \\
\text { Storytelling to Reconstruct } \\
\text { Traumatic Memories }\end{array}$ \\
\hline$\{$ Van Dijk $\}$ & 2016 & NL & Pregnancy & 357 & Questionnaire & Patient & $\begin{array}{l}\text { Impact of an mHealth } \\
\text { Platform for Pregnancy on } \\
\text { Nutrition and Lifestyle of } \\
\text { the Reproductive } \\
\text { Population: A Survey }\end{array}$ \\
\hline Van Leer & 2017 & US & $\begin{array}{l}\text { Voice } \\
\text { Therapy }\end{array}$ & 14 & $\begin{array}{l}\text { Questionnaire } \\
\text { Interview Task } \\
\text { Completion }\end{array}$ & Patient & $\begin{array}{l}\text { An iOS-based Cepstral } \\
\text { Peak Prominence } \\
\text { Application: Feasibility for } \\
\text { Patient Practice of } \\
\text { Resonant Voice }\end{array}$ \\
\hline Vorrink & 2016 & NL & COPD & 20 & Questionnaire & Patient & $\begin{array}{l}\text { A Mobile Phone App to } \\
\text { Stimulate Daily Physical } \\
\text { Activity in Patients with } \\
\text { Chronic Obstructive } \\
\text { Pulmonary Disease: } \\
\text { Development, Feasibility, } \\
\text { and Pilot Studies. }\end{array}$ \\
\hline Webb & 2017 & $\mathrm{AU}$ & Child Health & 85 & $\begin{array}{l}\text { Questionnaire } \\
\text { Interview }\end{array}$ & Patient & $\begin{array}{l}\text { Improving Patient- } \\
\text { Centered Care for Young } \\
\text { People in General Practice } \\
\text { With a Codesigned } \\
\text { Screening App: Mixed } \\
\text { Methods Study }\end{array}$ \\
\hline White & 2016 & $\mathrm{AU}$ & Child Health & 4 & $\begin{array}{l}\text { Think Aloud } \\
\text { Questionnaire } \\
\text { Task } \\
\text { Completion }\end{array}$ & Patient & $\begin{array}{l}\text { Theory-Based Design and } \\
\text { Development of a Socially } \\
\text { Connected, Gamified } \\
\text { Mobile App for Men } \\
\text { About Breastfeeding (Milk } \\
\text { Man). }\end{array}$ \\
\hline Williams & 2016 & US & Child Health & 19 & $\begin{array}{l}\text { Think Aloud } \\
\text { Questionnaire }\end{array}$ & Clinician & $\begin{array}{l}\text { Usability Testing and } \\
\text { Adaptation of the Pediatric } \\
\text { Cardiovascular Risk } \\
\text { Reduction Clinical } \\
\text { Decision Support Tool. }\end{array}$ \\
\hline Wood & 2017 & NO & $\begin{array}{l}\text { Mental } \\
\text { Health }\end{array}$ & 78 & $\begin{array}{l}\text { Think Aloud } \\
\text { Questionnaire } \\
\text { Task } \\
\text { Completion }\end{array}$ & Dual & $\begin{array}{l}\text { Reduction of Burnout in } \\
\text { Mental Health Care } \\
\text { Providers Using the } \\
\text { Provider Resilience Mobile } \\
\text { Application. }\end{array}$ \\
\hline Wozney & 2016 & CA & Ehealth & 30 & Questionnaire & Clinician & Usability, learnability and \\
\hline
\end{tabular}




\begin{tabular}{|c|c|c|c|c|c|c|c|}
\hline & & & $\begin{array}{l}\text { intervention } \\
\text { platform }\end{array}$ & & $\begin{array}{l}\text { Task } \\
\text { Completion }\end{array}$ & & $\begin{array}{l}\text { performance evaluation of } \\
\text { Intelligent Research and } \\
\text { Intervention Software: A } \\
\text { delivery platform for } \\
\text { eHealth interventions. }\end{array}$ \\
\hline Wray & 2017 & US & HIV & 10 & Interview & Patient & $\begin{array}{l}\text { eTEST: Developing a } \\
\text { Smart Home HIV Testing } \\
\text { Kit that Enables Active, } \\
\text { Real-Time Follow-Up and } \\
\text { Referral After Testing. }\end{array}$ \\
\hline Yen & 2016 & US & Arthritis & 48 & $\begin{array}{l}\text { Think Aloud } \\
\text { Task } \\
\text { Completion }\end{array}$ & Dual & $\begin{array}{l}\text { Usability and Workflow } \\
\text { Evaluation of "RhEumAtic } \\
\text { Disease activitY" } \\
\text { (READY). A Mobile } \\
\text { Application for } \\
\text { Rheumatology Patients and } \\
\text { Providers. }\end{array}$ \\
\hline Yoo & 2016 & KR & $\begin{array}{l}\text { Hospital } \\
\text { Navigation }\end{array}$ & 76 & $\begin{array}{l}\text { Think Aloud } \\
\text { Questionnaire } \\
\text { Task } \\
\text { Completion }\end{array}$ & Dual & $\begin{array}{l}\text { A personalized mobile } \\
\text { patient guide system for a } \\
\text { patient-centered smart } \\
\text { hospital: Lessons learned } \\
\text { from a usability test and } \\
\text { satisfaction survey in a } \\
\text { tertiary university hospital }\end{array}$ \\
\hline Yuen & 2016 & US & $\begin{array}{l}\text { Disaster Self } \\
\text { Help }\end{array}$ & 24 & $\begin{array}{l}\text { Think Aloud } \\
\text { Questionnaire } \\
\text { Interview }\end{array}$ & Patient & $\begin{array}{l}\text { Development and } \\
\text { preliminary testing of a } \\
\text { web-based, self-help } \\
\text { application for disaster- } \\
\text { affected families. }\end{array}$ \\
\hline
\end{tabular}


Table: List of Health Conditions addressed by Ehealth apps in retrieved papers.

Health Condition/ Disease

Mental Health

Cancer

Nutrition

Child Health

Diabetes

Telemedicine

CVD

HIV

Health Info System

Smoking

Alcohol

Chronic Conditions

Exercise

Pregnancy

Arthritis

COPD

Dementia

EHR

Fall Prediction Detection

Medication adherence

Metabolic Syndrome

Postoperative care

Tuberculosis

Adverse Drug Reactions

Aging

Brain Injury

CPR

Delirium

Dental

Dialysis

Disaster Self-Help

eHealth intervention platform

Elderly Wellbeing

Family Planning

Fibromyalgia

Geolocation Alarm

Head Injury

Homeless Youth

Hospital Navigation

Medical Education

Multiple Sclerosis

Ophthalmology

Parkinson's Disease

Physiotherapy

SLE

Spina Bifida

Stroke Rehab

Voice Therapy

Total

\section{Frequency}

12

10

10

9

9

10

6

4

4

4

3

3

3

3

2

2

2

2

2

2

2

2

2

1

1

1

1

1

1

1

1

1

1
1

1

1

1

1

1

1

1

1

1

1

1

133 

Table: List of Journals where selected articles were published.

\section{Journal Title}

JMIR mHealth and uHealth

Studies in health technology and informatics

JMIR Human Factors

BMC Medical Informatics and Decision Making 5

International Journal of Medical Informatics 5

Journal of Medical Internet Research 5

2016 38th Annual International Conference of the IEEE Engineering in Medicine 3

and Biology Society (EMBC)

JMIR research protocols

Applied clinical informatics

Health informatics journal 2

JMIR cancer 2

Journal of Biomedical Informatics 2

Journal of Health Communication 2

Nutrients 2

mHealth 2

2015 International Conference on Computational Science and Computational 1

Intelligence (CSCI)

2016 IEEE International Conference on Healthcare Informatics (ICHI) 1

2016 Sixth International Conference on Digital Information and Communication 1

Technology and its Applications (DICTAP)

2017 IEEE Symposium on Computers and Communications (ISCC) 1

2017 International Conference on Virtual Rehabilitation (ICVR) 1

AIDS Care 1

American Heart Journal

Applied Nursing Research 1

BMC Public Health 1

BMC neurology 1

Bio-medical materials and engineering 1

BioMed Research International 1

CIN: Computers, Informatics, Nursing 1

Community Mental Health Journal 1

Computer Methods and Programs in Biomedicine 1

European Journal of Oncology Nursing 1

European journal of physical and rehabilitation medicine 1

Frontiers in public health 1

Healthcare informatics research 1

IEEE journal of biomedical and health informatics 1

International Journal of Behavioral Nutrition and Physical Activity 1

International Journal of Telemedicine and Applications 1

International Journal of Telerehabilitation 1

International journal of human-computer interaction 1

International journal of mental health nursing 1

International journal of telerehabilitation 1

JMIR Rehabilitation and Assistive Technologies 1

JMIR medical informatics $\quad 1$

JMIR mental health 1

JMIR rehabilitation and assistive technologies 1

Journal of General Internal Medicine $\quad 1$

Journal of Medical Systems 1

Journal of Pediatric Health Care 1

Journal of Technology in Human Services 1

Journal of Telemedicine and Telecare 1 
Journal of Voice 1

Journal of diabetes research 1

Journal of health psychology 1

Journal of the American Medical Informatics Association: JAMIA 1

MCN, The American Journal of Maternal/Child Nursing 1

Medical education online 1

Midwifery 1

Pediatric Transplantation 1

Schizophrenia bulletin 1

Telemedicine and e-Health 1

Telemedicine journal and e-health : the official journal of the American 1

Telemedicine Association

The Journal of the American Dental Association 1

Tropical Medicine $\{\backslash \&\}$ International Health

Total 133

Table: List of Health Conditions addressed by Ehealth apps in retrieved papers.

\section{Health Condition/ Frequency}

Disease

Mental Health 12

Cancer 10

Nutrition 10

Child Health 9

Diabetes 9

Telemedicine 10

CVD 6

HIV 4

Health Info System 4

Smoking 4

Alcohol 3

Chronic Conditions 3

Exercise 3

Pregnancy 3

Arthritis 2

COPD 2

Dementia 2

EHR 2

Fall Prediction 2

Detection

Medication adherence 2

Metabolic Syndrome 2

Postoperative care 2

Tuberculosis 2

Adverse Drug Reactions 1

Aging 1

Brain Injury 1

CPR 1

Delirium 1

Dental 1

Dialysis 1

Disaster Self-Help 1

eHealth intervention 1

platform

Elderly Wellbeing 1

Family Planning 1

Fibromyalgia 1 
Geolocation Alarm 1

Head Injury 1

Homeless Youth 1

Hospital Navigation 1

Medical Education 1

Multiple Sclerosis $\quad 1$

Ophthalmology 1

Parkinson's Disease 1

Physiotherapy 1

SLE 1

Spina Bifida 1

Stroke Rehab 1

$\begin{array}{ll}\text { Voice Therapy } & 1 \\ \text { Total } & 133\end{array}$ 